\title{
Volcanism and Historical Ecology on the Willaumez Peninsula, Papua New Guinea ${ }^{1}$
}

\author{
Robin Torrence, ${ }^{2}$ Vince Neall, ${ }^{3}$ and W. E. Boyd ${ }^{4}$
}

\begin{abstract}
The role of natural disasters has been largely overlooked in studies of South Pacific historical ecology. To highlight the importance of rapid-onset natural hazards, we focus on the contributions of volcanism in shaping landscape histories. Results of long-term research in the Willaumez Peninsula on New Britain in Papua New Guinea illustrate the wide range and complexity of potential relationships between volcanic activity and human responses. Despite frequent severe volcanic impacts, human groups have responded creatively to these challenges and over time may have developed particular strategies that coped with the demands of repeated refuging and recolonization.
\end{abstract}

IN THE PIONEERING book on historical ecology in the Pacific region, Matthew Spriggs rightly identified the key determinants of landscape evolution as (1) climate change, (2) natural disasters, and (3) human agency. Like the majority of the other contributions, he barely mentioned the second category, which included "catastrophic events or sequences of events, such as volcanic eruptions, earthquakes or hurricanes" (Spriggs 1997:80). Instead, the majority of Pacific scholars have focused on natural and cultural processes that played out gradually over relatively long periods of time. The lack of attention to rapid-onset natural hazards is a serious flaw in our understanding of historical ecology in this area because their sudden and violent impacts pose a special challenge for human soci-

\footnotetext{
${ }^{1}$ Funding was provided by Australian Research Council, Australian Museum, Earthwatch Institute, Australia and Pacific Foundation, Pacific Biological Foundation, New Britain Palm Oil, Ltd. Manuscript accepted 15 January 2009.

${ }^{2}$ Australian Museum, 6 College Street, Sydney, New South Wales 2010, Australia.

${ }^{3}$ Institute of Natural Resources, Massey University, Private Bag 11 222, Palmerston North, New Zealand.

${ }^{4}$ School of Environmental Science and Management, Southern Cross University, Lismore, New South Wales 2480, Australia.
}

Pacific Science (2009), vol. 63, no. 4:507-535

(C) 2009 by University of Hawai'i Press

All rights reserved eties (cf. Cronin et al. 2008:2192-2193). Recent scholarship in archaeology, however, well reflects a growing awareness resulting from modern disasters (e.g., Grattan and Torrence 2007:1, Cashman and Giordano 2008). Our paper redresses the imbalance of research efforts in Pacific historical ecology by highlighting the relative roles of natural and anthropogenic factors in the formation of landscape histories played out in settings subject to natural disasters. To better illustrate the general processes, we provide concrete cases based on our interdisciplinary research on the Willaumez Peninsula in $\mathrm{Pa}$ pua New Guinea.

Although a range of natural disasters may comprise important elements of local historical ecology, we focus here primarily on volcanic activity because its role has been noticeably absent in previous studies of South Pacific historical ecology. This omission is surprising because volcanism has been an important element in the formation of these environments. In many cases it may also have seriously restricted the degree to which human agency could shape landscape histories. Many prehistoric human groups experienced explosive eruptions, as dramatically illustrated by the burial of well-known South Pacific archaeological sites under volcanic deposits (e.g., Garanger 1972, Specht et al. 1988, Cronin and Neall 2000, Anson et al. 2005, Bedford et al. 2006). Cultural landscapes impacted by repeated volcanic hazards share general characteristics that set them apart 
from more stable settings and those that experience slow climatic change. Extreme levels of selection operate in these "catastrophic environments," defined by Torrence and Doelman (2007:43) as those that experience "frequent, very severe environmental perturbations," each of which is serious enough to cause local extinctions (cf. Hoffmann and Parsons 1997:23, Turner and Dale 1998). In these situations human societies are unable to modify their behavior and remain in place permanently. Instead, the archaeological record of catastrophic volcanic settings is characterized by cycles of abandonment and (re)colonization (e.g., Sheets et al. 1991, Sheets and McKee 1994, Siebe et al. 1996, Sheets 1999, 2007, Machida and Sugiyama 2002, Mastrolorenzo et al. 2002, 2006, Zeidler and Isaacson 2003, Gaillard et al. 2007). In addition, the repeated occurrence of disasters often disrupts natural processes of succession so that the environment is permanently maintained in a relatively disturbed and immature state, a condition that in turn may yield special opportunities for colonizing populations. Despite the devastating consequences of volcanic activity, the fertile soils and useful raw materials (e.g., obsidian) provide strong inducements for human settlement.

Although settings characterized by high rates of volcanism comprise a substantial risk for cultural groups, recent scholarship has shifted from focusing solely on the environmental forcing agent to a consideration of the vulnerability of societies, which in turn is linked to factors such as social complexity, population, and intensity of land use (Torrence and Grattan 2002:5). This new orientation has had its problems, however, because humans are conceived as victims rather than as active agents who creatively shape their responses to natural disasters. A better solution is to consider vulnerability, environmental hazards, and recovery as linked processes that unfold over long periods of time (Grattan and Torrence 2007:3). The complex interactions between violent events, useful volcanic products, and human agency comprise fascinating material for analysis using the perspectives of historical ecology.
As a first step in encouraging studies of historical ecology in South Pacific volcanic environments, we review the basic types of hazards commonly found in these settings. Following the general description of each type, we draw on case studies from the Willaumez Peninsula, New Britain, Papua New Guinea, to illustrate how each component of volcanism contributed to the historical ecology. The case studies are devised to achieve two goals. First, they illustrate the wide range of field and analytical methods that contribute to the reconstruction of historical ecology in volcanic settings. Second, they provide a springboard for a general discussion of the potential role of explosive volcanism in historical ecology, not only in the South Pacific area but also worldwide.

\section{EXPLOSIVE VOLCANISM IN THE SOUTH PACIFIC}

In this paper we focus on explosive volcanism that is typically derived from the plinian style of volcanic activity rather than the effusive volcanism classically associated with the $\mathrm{Ha}$ waiian style of eruption. In the South Pacific, plinian volcanism is located at the convergent plate boundaries where subduction is occurring. Good examples include the following volcanically active areas: the Solomon Islands, Vanuatu, Tonga, the Kermadec arc, and the North Island of New Zealand. In the Papua New Guinea region a complex of microplates forms a buffer between movement of the large Australian and Pacific plates. In our study area, on the island of New Britain, it is the Solomon Sea microplate to the south that is being subducted northward beneath the South Bismarck microplate (Bird 2003). This is occurring at a rate of about $100 \mathrm{~mm}$ per year in the region of our case study in the Willaumez Peninsula (Wallace et al. 2004). Plate tectonics has led to an array of explosive volcanism throughout New Britain that reflects magma generation from different depths across the subduction zone that progressively deepens to the north (Johnson 1976, Woodhead et al. 1998). Our research has focused on volcanic activity derived primarily from two calderas that have been the 


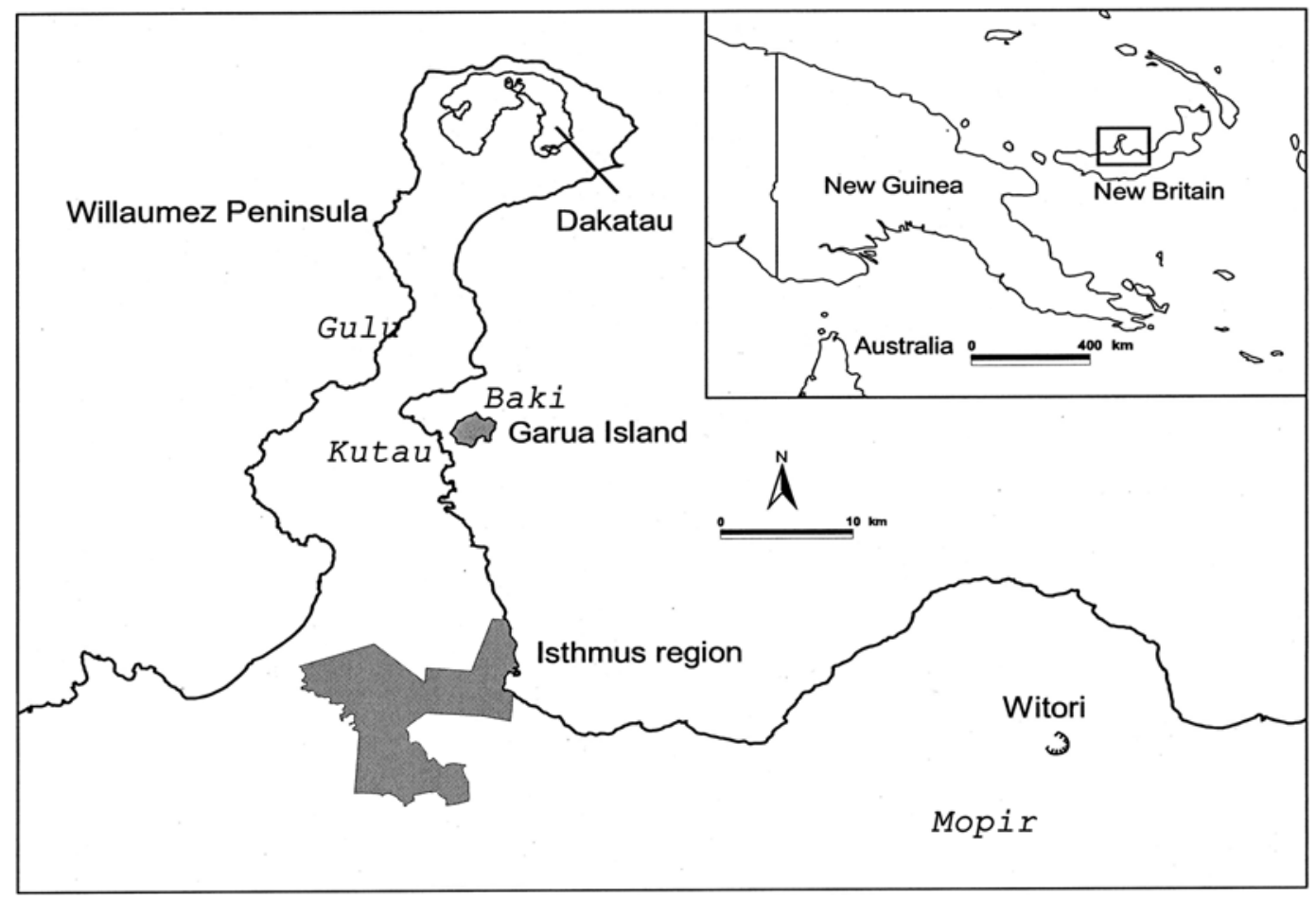

Figure 1. Location of study areas on Garua Island and the isthmus region of the Willaumez Peninsula, two volcanic centers (Dakatau and Witori), obsidian sources (in italics), and other places mentioned in the text.

source of major plinian eruptions in the Holocene. These are the Witori volcanic center, $50 \mathrm{~km}$ east of the Willaumez isthmus, and the Dakatau volcanic center at the northern tip of the Willaumez Peninsula (Figure 1).

\section{TEPHRA STRATIGRAPHY}

Although volcanic activity often causes a cultural disaster, ironically the same event may benefit later generations of archaeologists. The spectacular sites of Pompeii (e.g., Sigurdsson et al. 1985) and Ceren (Sheets 1992, 2002) illustrate how whole towns or villages and their contents have been buried and therefore preserved by deep falls of volcanic ash and/or lapilli or pyroclastic-flow deposits. Airborne ash (technically "airfall tephra") can also cover entire landscapes and freeze them in time. If there are multiple eruptions, a "layer cake" of volcanic deposits interbedded with levels of cultural material is formed. This tephra stratigraphy provides the essential backbone for relative dating and enables archaeologists, earth scientists, and physical geographers to correlate layers with distinctive physical and/or chemical characteristics over large areas (e.g., Sheets et al. 1991, Sheets and McKee 1994, Cronin and Neall 2000, Torrence et al. 2000, Lowe et al. 2002, Machida and Sugiyama 2002, Zeidler and Isaacson 2003, Neall et al. 2008, Torrence 2008).

Research into the interaction of human societies with the catastrophic environment of the Willaumez Peninsula, Papua New Guinea, provides a good example of the importance of a good tephra stratigraphy. In this case interdisciplinary research has built a regional Holocene tephra stratigraphy comprising nine explosive volcanic eruptions and 
TABLE 1

Summary of Volcanic Activity Recorded in the Archaeological Record of Garua Island and the Isthmus Regions in the Willaumez Peninsula

\begin{tabular}{|c|c|c|c|}
\hline Volcanic Event & Type $^{a}$ & $\begin{array}{c}\text { B.P. Date } \\
\left(\text { Based on TL) }{ }^{b}\right.\end{array}$ & $\begin{array}{l}\text { B.P. Date (Based } \\
\text { on Radiocarbon) }{ }^{c}\end{array}$ \\
\hline \multicolumn{4}{|l|}{ Holocene } \\
\hline W-H6 & Plinian, subplinian, VEI 4 & & $<500^{d}$ \\
\hline W-H5 & Phreatomagmatic, VEI 4 & & $<500^{d}$ \\
\hline W-H4 & Plinian, VEI $4 / 5$ & & $<500^{d}$ \\
\hline W-H3 & Phreatomagmatic, VEI 4 & & $<500^{d}$ \\
\hline $\mathrm{W}-\mathrm{K} 4$ & $\begin{array}{l}\text { Phreatomagmatic, plinian, } \\
\text { ignimbrite forming, VEI } 5\end{array}$ & & $1,310-1,170^{c}$ \\
\hline $\mathrm{Dk}$ & $\begin{array}{l}\text { Phreatomagmatic, plinian, } \\
\text { ignimbrite forming, VEI } 5\end{array}$ & & $1,350-1,270^{c}$ \\
\hline $\mathrm{W}-\mathrm{K} 3$ & Plinian, VEI 5 & & $1,740-1,540^{c}$ \\
\hline Garbuna & Pyroclastic flow & & ca. $1800^{e}$ \\
\hline $\mathrm{W}-\mathrm{K} 2$ & $\begin{array}{l}\text { Phreatomagmatic, plinian, } \\
\text { ignimbrite forming, VEI } 5\end{array}$ & & $3,480-3,160^{c}$ \\
\hline Unknown, east of Garbuna & Pyroclastic flow & & $4,200^{e}$ \\
\hline $\mathrm{W}-\mathrm{K} 1$ & $\begin{array}{l}\text { Plinian, ignimbrite forming, VEI } \\
5-6\end{array}$ & & $6,160-5,740^{c}$ \\
\hline Kulu tuff & Subplinian, phreatomagmatic & & $>\mathrm{W}-\mathrm{K} 1$ \\
\hline Numundo Maar & Subplinian, phreatomagmatic & & $<7500^{e}$ \\
\hline \multicolumn{4}{|l|}{ Pleistocene } \\
\hline Tephra H: Kupona na Dari & $\begin{array}{l}\text { Long period of small dustings of } \\
\text { airfall tephra }\end{array}$ & $23,200 \pm 6,100$ & \\
\hline Tephra G: Kupona na Dari & $\begin{array}{l}\text { Long period of small dustings of } \\
\text { airfall tephra }\end{array}$ & & \\
\hline Tephra F: Kupona na Dari & $\begin{array}{l}\text { Long period of small dustings of } \\
\text { airfall tephra }\end{array}$ & & \\
\hline Tephra Lower E: Kupona na Dari & Local subplinian or distal plinian & $\begin{array}{l}39,8000 \pm 5,200 \\
38,000 \pm 10,4000\end{array}$ & \\
\hline $\begin{array}{l}\text { Tephras D1 and D2: Kupona na } \\
\text { Dari }\end{array}$ & Subplinian eruption & & \\
\hline Tephra Upper C: Kupona na Dari & $\begin{array}{l}\text { Long period of small dustings of } \\
\text { airfall tephra }\end{array}$ & & \\
\hline Tephra Middle C: Kupona na Dari & $\begin{array}{l}\text { Long period of small dustings of } \\
\text { airfall tephra }\end{array}$ & & \\
\hline Tephra C: Kupona na Dari & Plinian eruption & & \\
\hline Tephra B: Kupona na Dari & $\begin{array}{l}\text { Long period of small dustings of } \\
\text { airfall tephra }\end{array}$ & & \\
\hline Tephra B1: Kupona na Dari & $\begin{array}{l}\text { Long period of small dustings of } \\
\text { airfall tephra }\end{array}$ & & \\
\hline Tephra A: Kupona na Dari & $\begin{array}{l}\text { Series of eruptions in quick } \\
\text { succession culminating in a } \\
\text { plinian eruption }\end{array}$ & $36,000 \pm 3,900$ & \\
\hline
\end{tabular}

\footnotetext{
${ }^{a}$ VEI, Volcanic Explosivity Index.

${ }^{b}$ Full dates reported in Torrence et al. (2004b). TL, thermoluminescence.

${ }^{c}$ Based on Bayesian modeling as reported in Petrie and Torrence (2008), except where noted.

${ }^{d}$ Based on unpublished dates and Machida et al. (1996:71, fig. 4).

${ }^{e}$ Based on McKee et al. (2005:17-18, table 1).
}

identified four minor episodes with a more restricted distribution (Table 1). These distinctive strata are used to correlate events among archaeological and environmental contexts spread across the entire region. As the result of extensive collaboration among (1) the archaeologists who expose numerous deep stratigraphic sequences through excava- 
tions and locate others through field survey; (2) the geologists, geochemists, and soil scientists who interpret and characterize the layers; and (3) dating experts, a highly useful tephrochronology has been reconstructed based on five of the volcanic eruptions that impacted the Willaumez Peninsula during the Holocene (e.g., Specht et al. 1991, Machida et al. 1996, Torrence et al. 2000, Torrence 2002a, McKee et al. 2005, Neall et al. 2008; cf. Pavlides 2006) (Figure 2). A Bayesian analysis of radiocarbon dates provides excellent chronometric control for the Witori and Dakatau eruptions, thereby anchoring the tephra stratigraphy in time (Table 1) (Petrie and Torrence 2008). The Pleistocene volcanic history of the region is much less known because these layers are very deeply buried and their diagnostic properties obscured through extreme weathering in these tropical conditions, but studies of several key sections on Garua Island and at the Kupona na Dari site on the mainland, together with luminescence and fission track dating, provide a small window into human/volcano interactions for the earliest periods of human settlement (Torrence et al. 2004a,b, Lentfer and Torrence 2007) (Table 1).

The Holocene tephrochronology in the Willaumez Peninsula comprises the backbone for dating the archaeological deposits and has also been invaluable for studying landscape changes. Given the great thicknesses of material deposited near the volcanic center (e.g., Figure 3), one has to be careful in choosing a region where the full tephra stratigraphy can be accessed. The most practical solution is to focus on regions that were impacted only by airfall tephra (i.e., "ash") with thicknesses of $1 \mathrm{~m}$ or less, so that archaeological data are well preserved but still reasonably accessible. The two study regions that we have selected, Garua Island and the isthmus area at the southern end of the peninsula, are ideal sites for studying the impacts of tephra falls because they are located between the two major volcanic centers at Witori and Dakatau (Figure 1).

The history and character of human social life and land use during the Holocene has been reconstructed through the interpreta- tion of materials recovered from ca. 140 test pits (mainly $1 \mathrm{~m}^{2}$ ) that are distributed widely across the two study areas (Figure 4) (Torrence 2002a,b, 2004a, Specht and Torrence $2007 a$, Torrence and Doelman 2007). Utilizing expertise on geomorphology, plant microfossils, diatoms, and coral ecology, the research team has also reconstructed the historical ecology in terms of (1) natural factors, including relative sea level change and volcanic activity and its consequences, such as earthquakes, erosion, and tsunamis (e.g., Boyd and Torrence 1996, Torrence et al. 1996, Boyd et al. 1999, 2005, White et al. 2002, Jago and Boyd 2005, Neall et al. 2007, 2008, Specht and Torrence 2007b), as well as (2) anthropogenic processes of land management such as burning and plant translocation (e.g., Parr et al. 2001, Boyd et al. 2005, Lentfer and Torrence 2007). Unfortunately, due to the lack of contexts that preserve pollen, it has not been possible to adequately address climatic change in this research.

\section{VOLCANIC HAZARDS}

Geologists generally use the Volcanic Explosivity Index (VEI) of Newhall and Self (1982) to rank the scale of volcanic eruptions. Those in the range of VEI 4 to 8 are classed as cataclysmic or paroxysmal eruptions involving the eruption of between 1 and $10,000 \mathrm{~km}^{3}$ of pyroclasts to heights of 10 to $>25 \mathrm{~km}$ (Pyle 2000). These eruptions pose very serious consequences for human groups, particularly for those living fairly close to the eruptive center. A good example is the 1991 eruption of Pinatubo of VEI 6 that forced evacuation of a very large area, much of which is still not able to be safely recolonized, and also affected global temperatures (Newhall and Punongbayan 1996). Gaillard et al. (2007:225) noted that the "eruption and its aftermath caused economic losses estimated at a billion US dollars, and wreaked havoc in the lives of two million people." As shown in Table 1 , most of the Holocene eruptions from our case study in the Willaumez Peninsula were VEI 5 or slightly higher, therefore posing extreme danger to human inhabitants. Also, given that the volcanic events consistently generated se- 


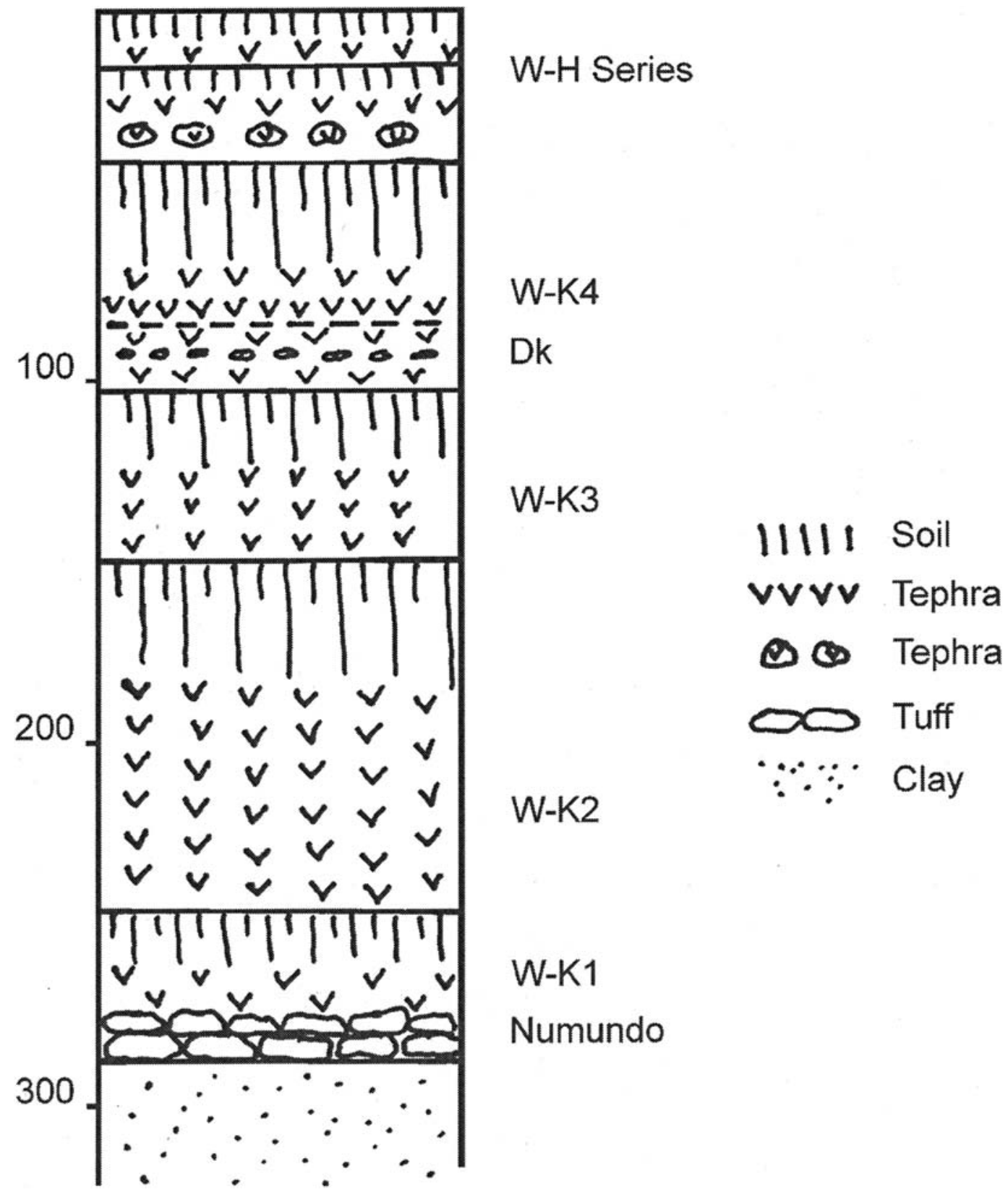

Figure 2. Holocene tephra stratigraphy in the Willaumez Peninsula.

vere hazards for human societies over a long period of time, we can be in no doubt that the Willaumez Peninsula qualifies as a "catastrophic environment."
It is important to consider both the potential positive as well as negative impacts of volcanic hazards. Beyond the destruction zone, many of these same catastrophic processes 


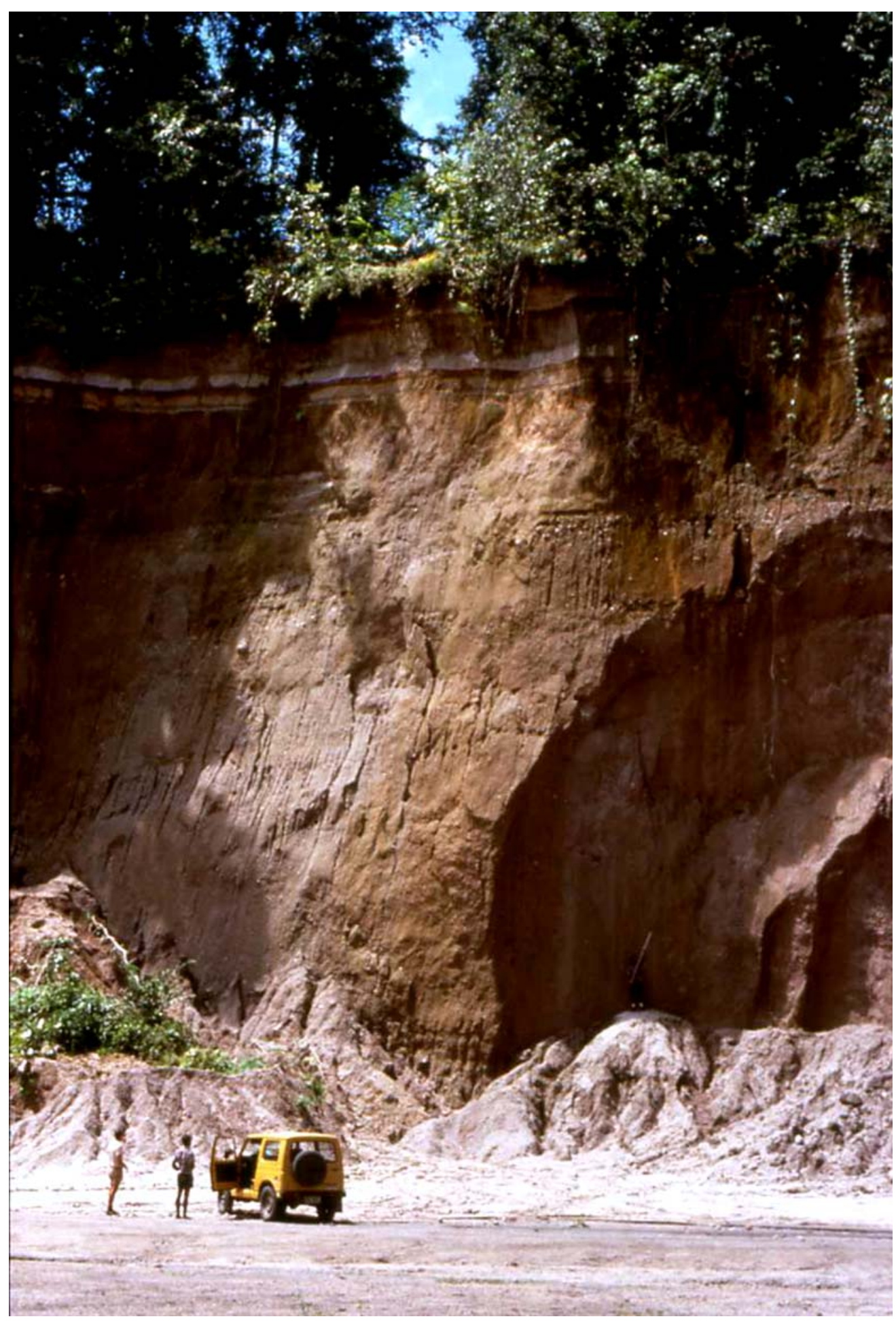

FIGURE 3. The human scale provides a good indication of the devastation that must have been caused by this pyroclastic flow derived from the $\mathrm{W}-\mathrm{K} 2$ eruption. This location is ca. $10 \mathrm{~km}$ from the Witori caldera. 

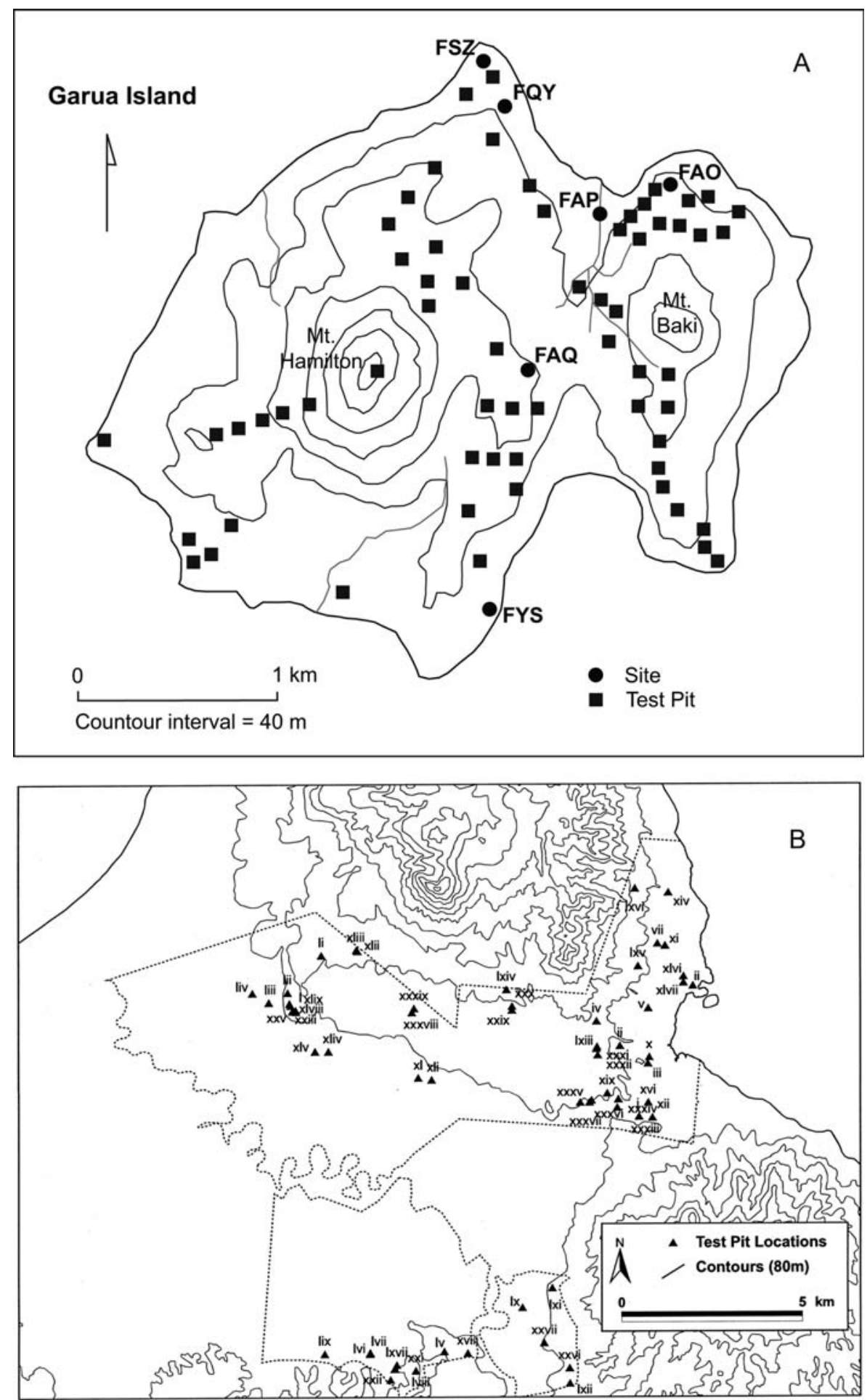

Figure 4. Location of archaeological excavations on $(A)$ Garua Island and $(B)$ the isthmus region of the Willaumez Peninsula. 
also provide new opportunities for humans through the creation and remodeling of landscapes, the production of useful raw materials, and enhancement of soil nutrients (Grattan and Torrence 2007). We consider the following key factors: (1) seismic activity; (2) tsunamis; (3) explosive eruptions that generate noxious gases, tephras, and lavas; and (4) geothermal activity. With the exception of geothermal activity, all of these happen suddenly, although with various degrees of prior warning. In addition, the scale and length of time over which they occur cover a large range. These natural hazards are markedly different from the low-risk, slow-onset variables that have been well described in studies of Pacific historical ecology. Having introduced the important concepts about volcanism and summarized our methods, we now turn to a discussion of the major factors that have conditioned historical ecology in Pacific volcanic environments.

\section{SEISMIC ACTIVITY}

Due to the continuing movement of the Australian and Pacific lithospheric plates, much of the South Pacific region is characterized by active seismic activity, with accompanying earthquakes. Seismic activity varies in magnitude and frequency depending on the distance of a location from the active edge of each lithospheric plate or microplate. Most earthquakes result from faulting generated between the convergent or strike-slip (transcurrent) plate boundaries where plates are compressed and deformed by the processes of subduction or lateral offset. These earthquakes can show a large range in magnitudes and may represent some of the largest recorded. Lesser-magnitude earthquakes and volcanic tremors occur when magma makes its way toward the surface, and so ultimately these may accompany eruptive activity. This seismicity is usually localized within $10-50$ $\mathrm{km}$ of the volcanic center.

Turning to our case study, the effects of seismic activity are evident from many major faults visible on contour maps and aerial photos of the Willaumez Peninsula. Together with large landslides associated with them, many appear to date within the period of human occupation (e.g., McKee et al. 2005:11-13). Smaller faults that may have been associated with one or more earthquakes have also been identified during fieldwork. Movement along these could have led to collapses and landslides that had adverse effects on human settlements and gardens, although they might also have created new clearings in the forest that promoted the growth of early colonizing or sun-loving species like wild taros that were beneficial for human groups or created opportunities for new gardens. Although we have not yet observed clear connections between these features and human responses, it is worth stressing that, as in the present day, ancient people in the Willaumez Peninsula would have regularly experienced earthquakes of various degrees. Some of these would have caused local modifications and possible disruptions to drainages, forest resources, gardens, and settlements.

Within Garua Harbour there is abundant evidence for both localized uplift and subsidence caused by relatively recent tectonic activity (see review in Specht and Torrence [2007b:134-135, plate 6]). Among the most obvious are large areas of dead corals that have been uplifted as much as $1 \mathrm{~m}$ above the high-tide mark since 1973. Also, in another area Torrence and Webb (1992; cf. Boyd and Torrence 1996) reported lines of oysters together with dead corals that are currently about $1 \mathrm{~m}$ above high-water mark. These indicate a sudden uplift episode interpreted as representing a large earthquake and are radiocarbon dated to ca. 410-185 cal. B.P. (Specht and Torrence 2007b:135, plate 5). Although the evidence for this earthquake is best preserved along the coast, its effects would probably have been more widespread. Such an event could have caused severe damage to houses in the local area that might have led to fatalities, and, crucially, it might also have generated a tsunami.

\section{TSUNAMIS}

Tsunamis are a wave or series of waves that may suddenly inundate a coastline irrespec- 
tive of the meteorological conditions. Their nonmeteorological origin distinguishes them from storm waves. At sea they may travel very fast, at speeds of $1,000 \mathrm{~km} / \mathrm{hr}$, but in shallower waters they lose energy by frictional loss, interacting with the seafloor to slow to $<65 \mathrm{~km} / \mathrm{hr}$. At the same time they build in height and may attain $>30 \mathrm{~m}$. They are most often generated by a displacement of the seafloor caused by tectonic faulting but are also created by accompanying earthquakes triggering submarine landslides or by collapse of volcanic edifices into the sea. Because they often travel over large distances, tsunamis can impact on groups well outside the source region, but those living close to active tectonic environments and volcanoes near the sea are generally at higher risk. Tsunamis are a formidable hazard that has not been given as much attention by archaeologists as is merited given the strengths of their impacts on mortality. A review of historical records concerning tsunamis created by volcanism found that these were responsible for as much as a quarter of the total deaths associated with volcanic events (Neall 1996).

In the Willaumez Peninsula case, deposits that can be ascribed to tsunamis are surprisingly rare given the large number of explosive volcanoes and evidence for earthquakes. So far, the only example is on Boduna Island within Garua Harbour (White et al. 2002), but its effects on the local population are unknown. The $30 \mathrm{~cm}$ thick paleotsunami deposit consists of a coarse limestone gravel with a gray sandy matrix that is sandwiched within the well-established regional ash sequence. Older red brown, clay-rich tephras underlie the deposit, and almost $0.5 \mathrm{~m}$ of yellow brown friable loamy tephra overlies it.

Archaeological evidence for cultural disasters due to tsunamis in other areas of the South Pacific is also quite scarce, perhaps because in the past, people avoided placing their settlements in places they knew were risky based on past experiences (cf. Davies 2002). The Kurvot site in Vanuatu, where tsunami deposits overlie cultural material, is a notable exception. Galipaud (2002:166) noted that this natural disaster may have had a longterm effect on local groups because subse- quent settlements were shifted away from the dangerous coastal zone. Overall, the situation may resemble that for the North Pacific discussed by Johnson (2002), Saltonstall and Carver (2002), and Losey (2005), who all stress that societies have been extremely resilient in the face of earthquakes and associated tsunamis and point out that these may even be conceived of as beneficial because they have led to the creation of new land (but cf. Begét et al. [2008] for a different view).

The impacts of tsunamis are quite limited in spatial terms, generally within $50-150 \mathrm{~m}$ of the shoreline (e.g., Davies 2002:30). Because the potentially dangerous area is more predictable than most volcanic hazards, groups can easily avoid the most serious consequences simply by placing their settlements outside that zone. Along these lines, it is interesting that through time, settlements on Garua Island appear to have been increasingly focused on inland zones rather than on the beach (Torrence 2002b), although older coastal sites may have been removed by erosion following recent uplift.

\section{NOXIOUS GASES}

Highly acidic and noxious gases can be associated with explosive eruptions. They comprise steam, carbon dioxide, and sulfur dioxide that can be emitted in large quantities, and hydrochloric acid, hydrofluoric acid, and ammonia in lesser amounts. All these gases are harmful if inhaled because they harm the respiratory system and irritate eyes and skin, sometimes causing acid burning. The effects are likely to be most severe on those living close to the volcano, particularly in low-lying areas where gases heavier than air may accumulate to toxic levels. On larger, high-elevation volcanoes the effects are less dramatic because the gases are likely to be dissipated by the wind (for an exception see Grattan et al. [2002, 2007]), but a downdraft could concentrate gases in a localized area. The most disastrous case of mortality from noxious gases was in 1986 when an estimated 240,000 metric tonnes of $\mathrm{CO}_{2}$ was suddenly released from Lake Nyos in Cameroon asphyxiating 1,746 people and 3,000 cattle in 
nearby valleys (Neall 1996). Identifying the consequences of noxious gases in prehistoric cases is only possible when human remains have been preserved, but their consequences are still worth considering when reconstructing the potential hazards experienced in the past.

\section{TEPHRAS}

Tephras comprise the most common and, generally, the largest-scale hazard created by explosive eruptions. Depending on the amount of material deposited, which is determined by the magnitude of the eruption, both the pyroclastic flows and airfall tephra that accompany this class of hazard can have extremely negative impacts on all life forms, and often they have markedly reshaped the physical environment. The various types of tephras and their impacts are well illustrated by the Willaumez Peninsula case study.

First, within the vicinity of the Witori and Dakatau volcanic centers, pyroclastic flows from a plinian eruption would have totally destroyed all human life and the plant and animal resources on which they depended, and would also have drastically altered the physiography. The scale of the pyroclastic flows in the Willaumez Peninsula varied among the five large Holocene eruptions, but the majority were restricted to within a ca. $20 \mathrm{~km}$ radius of each eruptive center. The W-K2 event was a notable exception. It generated pyroclastic flows tens of meters thick that traveled at great speeds (probably $>100 \mathrm{~km} / \mathrm{hr}$ ) as much as $40 \mathrm{~km}$, partially by "skating" across Kimbe Bay, although they may have moved only along a relatively narrow path (Machida et al. 1996). We expect that many people would have escaped the direct effects of this type of hazard because there would have been considerable warning in the form of earthquakes. After very large eruptions, groups would probably have fled the most highly impacted regions. In contrast, some of the populations tens of kilometers away may have still been vulnerable to the flows.

Second, airfall tephras range in size from blocks, or volcanic bombs, the size of foot- balls to tiny particles less than $2 \mathrm{~mm}$ that are termed "ash" by volcanologists. In general, the farther one moves from the source, the smaller the size of the airfall material, but the scale of impact also depends on the magnitude of the eruption. Destruction of life forms from tephra can be caused by immediate impact or, over a broader area, by burial. Airfall tephras by themselves are rarely a direct cause of human mortality, except where they adversely affect air quality. Very dusty conditions, especially when the tephra contains toxic chemicals, can have immediate adverse impacts on health leading to death. In addition, if poisonous substances adhere to the surface of airfall tephras that have passed through a toxic eruption cloud, they can also cause harm (Grattan and Gilbertson 1994).

The main effect of tephras on humans is indirect through damage inflicted on essential resources, such as by fouling water supplies and destruction of the plant and animal communities on which they depend. The degree of impact depends on the chemical composition of the tephra, the presence of toxins on its surface, its thickness, and local conditions such as potential buffering through local vegetation and geology. For example, tephra with high amounts of fluorine can cause immediate mortality and make areas uninhabitable for very long periods of time through contaminating both water supplies and food crops, ultimately impacting on human health (Cronin 2006).

The severity of impacts resulting from airfall tephra also depends to a large degree on the climate and the season of the eruption because these set limits on how fast the biota can regenerate. For example, biological communities take much longer to recolonize areas buried by volcanic tephras in Alaska (e.g., Vanderhoek and Nelson 2007) than in tropical Pacific regions (e.g., Lentfer and Boyd 2001), although there will be further variation depending on how far seeds, spores, and recolonizing species have to travel (Thornton 1996). Based on previous studies, it has been observed that thicknesses greater than $50 \mathrm{~cm}$ of airfall tephra will strip the tropical forest canopy and destroy the ground cover to create a virtual desert. In the $20-50 \mathrm{~cm}$ thickness 
range trees will be defoliated, but some plants may be able to regenerate from buried roots and suckers or viable wood remaining aboveground. In lesser amounts of tephra, trees may be able to persist despite some loss of leaves, but many garden crops will not survive, especially in the absence of rainfall (Blong 1984:316-355, Lentfer and Boyd 2001, Torrence 2002a:301-302, Neall et al. 2008). The potential for regeneration also depends on the chemical content of the tephra, but in all cases it will be deficient in elements essential for plant growth such as nitrogen and will lack organic matter. Many volcanic soils are highly favorable for agriculture due to their textural properties and chemical composition, but these properties are not shared by freshly deposited tephra. Soil formation over at least a generation, even in a tropical setting, is required to support wild vegetation sufficient to sustain a population or even for successful gardening.

The Willaumez Peninsula case study has benefitted from large-scale field mapping of airfall tephra thicknesses (isopachs) by Machida et al. (1996). The regional picture has been enhanced by stratigraphic information collected from test pits in the isthmus study area (Figure 4). These data have been used to construct isopachs for the four Holocene Witori eruptions in the study area (Figure 5), providing an excellent basis for assessing the volcanic hazard generated by the five large eruptions from the Witori and Dakatau volcanoes during the Holocene (cf. Boyd et al. 1999).

Archaeological research by Pavlides (2006; pers. comm.) near Yombon in the southern foothills of the central Whiteman Range and the Lamogai Plateau found thicknesses of airfall tephra well over $20 \mathrm{~cm}$ from the $\mathrm{W}-\mathrm{K} 1$ and W-K2 eruptions, as much as $150 \mathrm{~km}$ from Witori, and smaller thicknesses of the other Witori and Dakatau events. Archaeological data from Garua Island and the Willaumez isthmus confirm that after the $\mathrm{W}-\mathrm{K} 1$ and $\mathrm{W}-\mathrm{K} 2$ eruptions, thicknesses of $>50 \mathrm{~cm}$ of tephra fell in both areas; the isthmus also experienced $>50 \mathrm{~cm}$ of $\mathrm{W}-\mathrm{K} 3$ tephra, lesser amounts of $\mathrm{W}-\mathrm{K} 4$, and only a trace of tephra from the Dakatau Dk eruption. Sites on
Garua had thicknesses of up to $1 \mathrm{~m}$ of $\mathrm{Dk}$ but only small amounts of $\mathrm{W}-\mathrm{K} 3$, and $\mathrm{W}$ K4 may be absent (Torrence and Doelman 2007: tables 3.2, 3.3).

The large volumes of airfall tephra that fell on the Willaumez Peninsula largely mantled the existing landscape, but they had more profound effects on coastal environments. A targeted study of the southeastern side of the isthmus based on data on buried corals, sediments, and phytoliths showed how the accumulation of thick layers of Witori tephras augmented by material eroded from nearby slopes considerably extended the coastal plain (Boyd et al. 2005).

\section{Unstable Tephras}

Even after an eruption has terminated, deep falls of tephra compose an important hazard. New hazards are generated by the instability of loose, unconsolidated tephra. The debris is frequently remobilized into lahars that pose very serious hazards to communities located downslope from the volcano. Depending on how long after the eruption they are formed, they may still be boiling hot. Because it can take several generations for the slopes to stabilize, lahars compose a long-term hazard around the base of the volcano, as illustrated by the ongoing damage caused through flows and flooding near Pinatubo, which erupted in 1991 (Crittenden and Rodolfo 2002, Gaillard et al. 2007). In this case the lahars have created (1) dams that form large lakes, but these regularly collapse, causing severe flooding; (2) vast, barren floodplains composed of coarse unsorted material; and (3) large tidal fans that have destroyed coastal resources.

After each eruption, remobilization of the tephras in the proximity of Witori Volcano probably reoriented drainage patterns, particularly in the floodplain of the Kapiura River to the north of the caldera. Massive alterations in landscape after the $\mathrm{W}-\mathrm{K} 2$ eruption would have radically altered access routes to the nearby Mopir obsidian outcrops (Figure 1). Together with risks caused by the ongoing instability of the tephras, it is not surprising that obsidian from this source largely disap- 
peared from archaeological sites for a considerable length of time after that eruption (e.g., Torrence et al. 1996, Summerhayes et al. 1998, Torrence 2004a).

Large-scale remobilization of tephras can also occur in regions quite distant from the volcano, leading to landslips, blockages of watercourses, and formation of coastal fans, and eventually to the creation of a coastal plain, as probably occurred on both Garua Island and on both coasts within the isthmus. The W-K1 tephra appears to have been particularly unstable, perhaps because it fell during the rainy season. It has a very patchy occurrence in the archaeological test pits in both our study areas, but thick redeposited layers are often identified in low-lying contexts (e.g., Specht et al. 1988:8-9 [Layer 3], Torrence et al. 1990:461 [ash in photos], Neall et al. 2008), suggesting possible redeposition by flooding.

\section{Distant Effects of Remobilization}

The enormous scale of potential landscape transformation resulting from the remobilization of deep falls of tephra can be hard to imagine, so we provide an example that is particularly impressive because the massive changes occurred at a considerable distance from the volcanic center. The data for this reconstruction were gathered through intensive mapping of horizons, benefitting from extensive modern drainage systems in the oil palm plantations combined with paleoenvironmental cores. Until about 6,000 years B.P. a large embayment on the west side of the Willaumez Peninsula (here termed Kulu Bay to distinguish it from the current Riebeck Bay) extended $17 \mathrm{~km}$ farther inland from the current coastline, covering an area of about 200 $\mathrm{km}^{2}$ (Figure 6). Coral dated at 6,733 \pm 32 years B.P. (Wk-15506) grew along the northern shoreline of this bay. After the W-K1 eruption between 6,150 and 5,770 cal. B.P., pumice was washed into the shallow waters of Kulu Bay, transforming the environment into a low-lying terrestrial swamp. After the $\mathrm{W}-\mathrm{K} 2$ eruption, the swampy environment was overwhelmed by a massive flood of pumice derived from the Kulu-Dagi River, inun- dating all the lowland. These redeposited beds are dominated by cross-bedded pumiceous fine and medium sands. They vary in places to fine pumiceous gravel; toward the upper contact clayey sand may be preserved. Small upward-fining sequences are preserved in some places with fine horizontal laminations.

Close to the point where the river exited from the surrounding hills, the redeposited surface steepens in gradient, narrows, and forms a prominent terrace on the Tili oil palm estate (here named the Tili surface). This demonstrates a massive discharge immediately after the $\mathrm{W}-\mathrm{K} 2$ eruption, around 3,500-3,200 cal. B.P., unlike any subsequent alluvial event in the region. Our interpretation is that either heavy rains remobilized $\mathrm{W}-\mathrm{K} 2$ pumice from the steep slopes of the headwaters of the Kulu-Dagi River immediately after the eruption (as happened around Mount Punatubo in 1991) and/or ephemeral dams may have been created from unstable debris, mobilizing large volumes of pumiceous sediment. By extrapolation, our estimates for the volume of redeposited material are between 0.2 and 0.4 million $\mathrm{m}^{3}$. This sediment was either carried directly by floodwaters or released by a sudden dam collapse to create a megaflood that radically transformed the lower catchment downstream of where it exits the hills. Consequently, much of the former Kulu Bay was infilled within a relatively short period of time.

\section{A Punctuated Prehistory}

More than a decade of research in the Willaumez Peninsula has produced a clear picture of the relationship between humans and natural disasters caused directly by airfall tephra or its remobilization. The Holocene volcanic eruptions led to a punctuated population history, characterized by repeated cycles of colonization and extinction, that when viewed overall yielded very slow population growth (Torrence and Doelman 2007). Whereas the long-term influence of volcanism on human history is to reduce the potential for growth, the role of specific disasters in causing shortterm cultural change is less clear. 

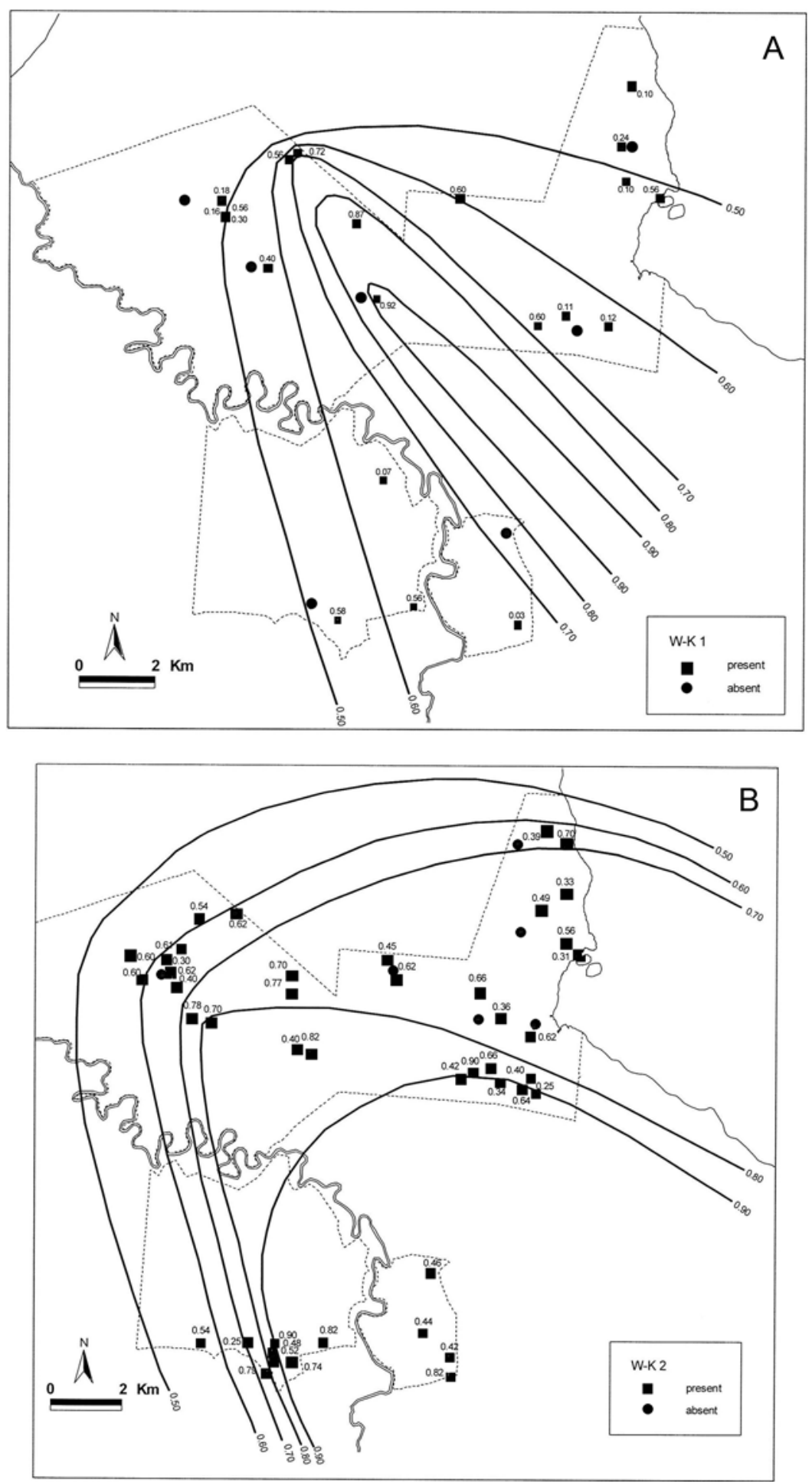

Figure 5. Isopachs of tephra thicknesses in the isthmus study area, Willaumez Peninsula. 

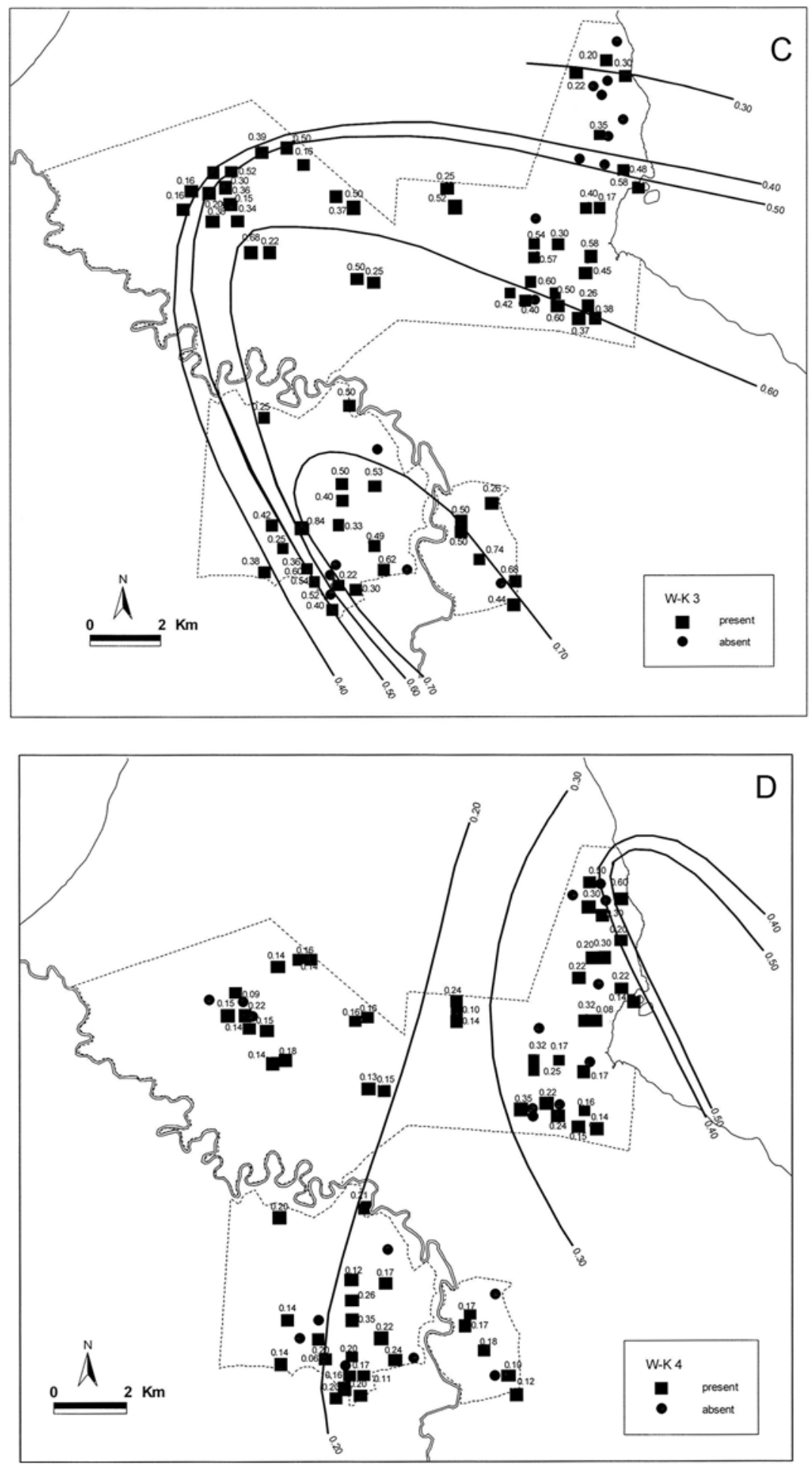

Figure 5. (continued) 


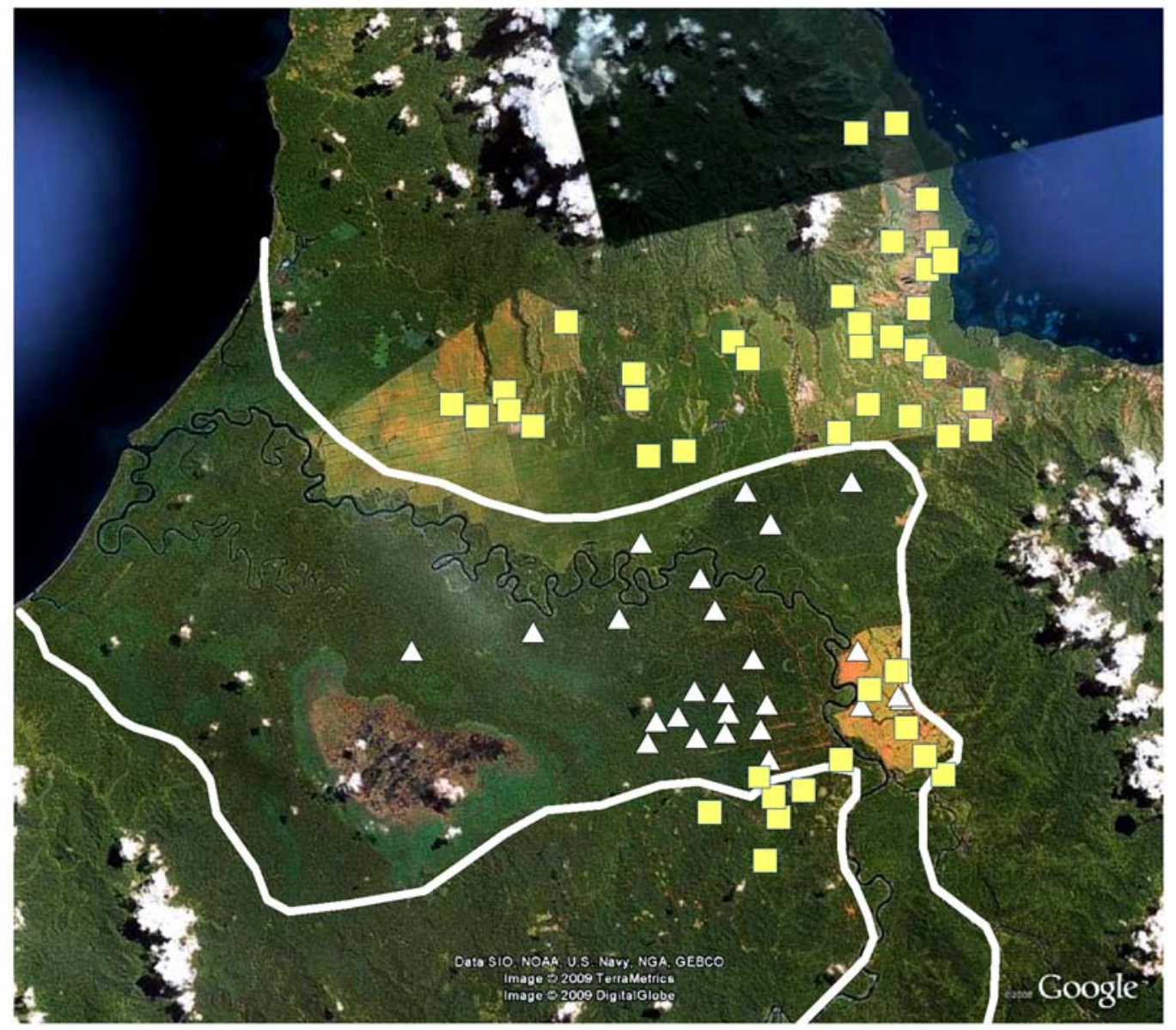

Figure 6. The white line shows the location of the ancient Kulu Bay, which was infilled following the W-K2 eruption. Triangles indicate positions where the Tili surface is currently exposed, and squares mark locations of archaeological test pits. (Base map reproduced with permission from Google Maps/Earth imagery.)

Given their potential impacts as measured by their thicknesses and the history of their redeposition, one would expect that the airfall tephras would have precipitated very serious cultural disasters after the $\mathrm{W}-\mathrm{K} 1$ and $\mathrm{W}-\mathrm{K} 2$ eruptions throughout the region stretching from Witori to at least $150 \mathrm{~km}$ to the west. The Dakatau Dk eruption would have devastated the northern end of the Willaumez Peninsula. After all these events, not only were the lands owned by people living in the study region made uninhabitable, but the homes and gardens of their neighbors were also destroyed, making it very difficult for populations to find refuge for the several generations necessary before resettlement would have been possible. Tephra thicknesses resulting from the $\mathrm{W}-\mathrm{K} 3$ event would also have forced abandonment of the two regions, although regeneration would have been much faster. W-K4 would have had serious impacts for the isthmus region but much less for Garua Island.

It is not surprising that the archaeological record shows local extinctions of human populations in the study areas following all the volcanic disasters. Even with Bayesian modeling, however, it is difficult to reconstruct the 
TABLE 2

Length of Abandonment after Volcanic Eruptions in the Willaumez Peninsula Based on Bayesian Modeling Reported in Petrie and Torrence (2008)

\begin{tabular}{llllll}
\hline \hline & \multicolumn{2}{c}{ Isthmus } & & \multicolumn{2}{c}{ Garua } \\
\cline { 2 - 3 } \cline { 5 - 6 } & $\begin{array}{c}\text { Interval } \\
95 \%\end{array}$ & & & $\begin{array}{c}\text { Interval } \\
\text { En }\end{array}$ \\
Eruption & \multicolumn{1}{c}{ HPD $^{a}$} & Mode & & HPD & Modes \\
\hline Post W-K1 & $1,350-2,000$ & 1710 & & $0-280$ & 110 \\
Post W-K2 & $0-300$ & 150,160 & & $0-300$ & 135,145 \\
Post W-K3 & $0-160$ & 55,70 & & $0-270$ & 95,110 \\
Post Dk & - & - & & $0-260$ & 215 \\
Post W-K4 & $0-170$ & 100 & & - & - \\
\hline
\end{tabular}

${ }^{a} \mathrm{HPD}$, highest posterior density.

exact periods of abandonment due to the statistical nature of radiocarbon chronology. If one uses the modes, it is clear that all the eruptions caused depopulation for long periods of time, and there is a general correlation between the scale of the airfall tephra and the length of abandonment (Table 2) (Petrie and Torrence 2008). This repeated pattern of extinction followed by colonization sets the parameters within which human populations had the potential to interact with the natural environment.

Clearly, the timing of the colonization in relation to the state of recovery of the ecosystem and the stabilization of sediments would have been critical. Did populations wait until the forest had completely regenerated or did some take advantage of the disaster to make gardens in land cleared as a consequence of the tephra falls? There is a hint in our data that people may have preferentially targeted hill- and ridgetops in the inland regions as the first places to recolonize, possibly because less tephra was preserved in those localities due to immediate posteruptive erosion (Torrence and Doelman 2007:56-59). Forest trees providing the only local terrestrial food sources may have survived in those locations. In contrast, the coastal zones would have been swampy and unstable due to the outflow of redeposited sediments that probably also had a negative effect on marine resources.

As shown in Table 2, when the data are viewed in terms of single eruptions, the correlation between strength of the volcanic forcing agent and human response is not totally straightforward, thereby indicating that cultural factors may have been important, perhaps along the lines of the "random" factors and "novelties" identified in the way natural systems have recovered from disasters (Hoffmann and Parsons 1997, Turner and Dale 1998). For instance, the very long period of abandonment after $\mathrm{W}-\mathrm{K} 1$ in the isthmus is difficult to account for solely on the basis of the volcanic disaster, especially when compared with $\mathrm{W}-\mathrm{K} 2$, whose impact was higher but not markedly so. This raises the question of whether W-K1 resulted in very widespread human mortality and exceptionally slow population growth in surrounding regions and/or there was some special reason (e.g., cultural concepts of place) why populations continued to avoid this region (Torrence and Doelman 2007:53). Similarly, the seemingly long gap after W-K3 on Garua Island does not have a clear relationship with the potential impact of the event, especially when compared with $\mathrm{W}-\mathrm{K} 2$ or $\mathrm{Dk}$, and so other factors must have affected the rate and nature of recolonization.

Another interesting point that arises from the case study is that the local extinction of a population due to a volcanic disaster does not necessarily lead to the collapse of a cultural system, although it may be a contributing factor to cultural change (cf. Manning and Sewell 2002 with Allison 2002, Driessen 2002). In the case of the Willaumez Peninsula, the manufacture and use of obsidian flaked tools that have distinctive stems or tangs, known as "stemmed tools" (Araho et al. 2002), survived the $\mathrm{W}-\mathrm{K} 1$ eruption despite the long period of abandonment. In contrast, the cultural practices associated with them disappeared after the $\mathrm{W}-\mathrm{K} 2$ eruption. At that time Lapita pottery was introduced to the Willaumez Peninsula. It is possible that the disaster resulting from $\mathrm{W}-\mathrm{K} 2$ seriously disrupted long-distance interaction indicated by the widespread distribution of stemmed tools in Melanesia, and this contributed to the appearance of Lapita-style pottery (Torrence and Swadling 2008).

Our discussion of the impacts of volcanic activity in New Britain on cultural change highlights the limitation of our case study in 
the Willaumez Peninsula. Although the data provide an excellent example of the general characteristics of human history that derive from a catastrophic volcanic environment, they are not adequate for understanding cultural changes because human societies typically operate over much broader scales. In fact, the large scale of social systems and the length of networks may actually be an outcome of adaptation to the catastrophic environment itself.

Not all explosive volcanic activity causes cultural disasters on as vast a scale as the large plinian eruptions from Witori and Dakatau. It is worth comparing these with a small eruption of the Numundo Maar volcano, located on the northern edge of the isthmus region (McKee et al. 2005:7-8). This small crater (ca. $500 \mathrm{~m}$ diameter) exploded pyroclastic surges, scoria, and ash on several occasions sometime shortly after ca. 7,500 B.P. Deposits from the most recent eruption have formed a hard layer of tuff up to $4 \mathrm{~m}$ thick at the maar, thinning to $2 \mathrm{~m}$ within $1 \mathrm{~km}$ away and to $0.5 \mathrm{~m}$ at $5 \mathrm{~km}$ distant from the crater. Such an event would certainly have caused concern to the local community (represented by artifacts that are stratified under the tephra), but it seems likely that they would have been able to readily escape the immediate danger. Over the longer term, the small area covered by the compacted tephra would not have been able to support vegetation for many years. Only after the W-K1 eruption deposited a layer of loose airfall tephra over the top of the tuff, creating a medium in which plants could eventually grow, was this relatively small area capable of sustaining a human population, as evidenced by the presence of dense archaeological deposits immediately overlying it. Despite its small scale, however, this event could nevertheless have impacted on cultural practice and ideology and perhaps been incorporated into local cultural memory through oral history and myth.

\section{USEFUL PRODUCTS}

From a human perspective, the most important benefits of volcanic lavas are their use as raw material for various types of stone tools. Many highly prized volcanic stones and glasses were widely exchanged in the $\mathrm{Pa}$ cific region both as raw materials and as finished products. The relatively coarse-grained stones were often used to make ground and polished axes and adzes, whereas the finegrained and glassy materials were flaked to yield sharp edges. Both types were also converted into distinctive shapes with important symbolic meanings that functioned as social currency (e.g., Firth 1959, Torrence 2004b, Specht 2005, 2007, Kirch and Kahn 2007). Communities living in the vicinity of these desirable raw materials had the potential to create social capital by monopolizing access to these resources, developing specialist skills for manufacturing products, and organizing their transport to other regions. Consequently, within the wider Pacific region many volcanic stones played important social roles within an island or island group and also circulated among populations separated by very large distances (e.g., Collerson and Weisler 2007, Summerhayes 2007).

Throughout the prehistory of the Willaumez Peninsula the most widely exchanged and valued volcanic stone was obsidian derived from three major source regions (Torrence et al. 1992) as well as from the Mopir source situated near the Witori Volcano (Fullagar et al. 1991). A shiny, distinctive stone such as obsidian would certainly appeal to the senses and is therefore perfectly suited for exchange (Torrence 2005). In the form of unworked nodules, partly worked cores or preforms, and as highly worked products representing skilled craftsmanship, obsidian was passed among local groups and transported over enormous distances (e.g., Specht 1981, Summerhayes et al. 1998, Rath and Torrence 2003, Torrence 2004a,b, Summerhayes 2007, Torrence and Swadling 2008, Torrence et al. 2009). In addition, volcanic lavas (primarily rhyolite) that were probably sourced locally were used in the production of ground stone implements from the mid-Holocene up to recent times (e.g., Specht 2005, 2007). Currently, little is known about whether and how they were traded, but the finding near Kimbe of a cache of 14 ground stone axe blades suggests that some were accumulated and traded as valuable objects. 
Obsidian was first transported and possibly exchanged as soon as people colonized the Willaumez Peninsula, and it continued to be moved over various geographical scales up until the recent past (Specht 1981, White 1996). Because obsidian exchange has persisted perhaps as long as 40,000 years, despite the discontinuous settlement history of the Willaumez Peninsula, it seems likely that this kind of cultural behavior might represent a form of adaptation to this catastrophic environment. The social links forged by the exchange of obsidian (and possibly also of ground stone tools as well as many perishable materials) could have provided access to crucial places of refuge and other forms of assistance for people who often suffered the disastrous consequences of volcanic activity (Torrence 2004b, Torrence and Doelman 2007:52-53). For this reason, the pattern of seeking out trading partners in other places was possibly maintained throughout the human history of the region.

\section{GEOTHERMAL ACTIVITY}

The most constant volcanic features in the Willaumez Peninsula are various forms of geothermal activity such as hot springs, boiling pools of mud, and geysers. Currently, the most active areas are at Pangalu and Talasea, on Boduna Island, along the east coast near the village of Patanga, at the top of Mount Garbuna, and scattered around the southern foot of Mount Garbuna (Heming and Smith 1969). Although the position of these geothermal areas is relatively stable, and, in general, they have had few detrimental effects on human life or resources, new areas arise from time to time and can render patches of forest or fields unsuitable for use. In 2005 and 2008 the geothermal area on the summit of Mount Garbuna experienced minor explosions of steam-bearing reworked sediments that lasted several weeks (Smithsonian Institution 2005), but so far there have not been serious negative consequences for human life or essential resources.

Geothermal activity in the Willaumez Peninsula has possibly produced as many positive as negative human impacts. These areas attract megapodes, flightless birds that lay their eggs in the warm soils. Both eggs and birds provide a predictable and rich source of food, although overexploitation is a possibility. Colorful soils formed near the hot springs at Talasea and near Patanga were used as pigments and traded widely in the past (Specht 1981). The hot water can also be useful as a medium for cooking.

\section{ANTHROPOGENIC FACTORS}

Given the scale and frequency of environmental changes in volcanic environments and the resulting necessity for abandonment, refuging, and recolonization, human populations are frequently faced with simple, depauperate ecosystems. In such cases one might question the potential for the types of anthropogenic factors so often stressed in previous studies of the historical ecology of South Pacific islands (e.g., human subsistence and land-use practices leading to extirpation, extinction, deforestation, and erosion [e.g., Anderson 1989, Enright and Gosden 1992, Kirch and Hunt 1997, Steadman 2006]).

Boyd and Torrence (1996) reported the results of a stratigraphic study of 30 sections largely from archaeological excavations on Garua Island supplemented by a study of coastal geomorphology (e.g., raised corals and fossilized beaches) on surrounding islands and the mainland. This was aimed at examining the possibility that prehistoric gardening practices led to periods of erosion as had been observed in other Pacific regions (e.g., Enright and Gosden 1992, Gosden and Webb 1994, Spriggs 1997). They noted that major episodes of erosion require the presence of exposed soils that can be mobilized by slope wash, slope creep, and runoff, and that human land clearance is only one potential cause. The destruction of vegetation due to the emplacement of airfall tephra is another factor that should be considered.

The Holocene sedimentary record on Garua Island holds remarkably little evidence for soil erosion. Boyd and Torrence (1996) described seven periods of erosion, identified with the assistance of the regional tephra stratigraphy, based on an analysis of $30 \mathrm{sec}-$ tions from archaeological sites, but only one of these, dating to the twentieth century, was 
convincingly associated with human activity. Only the earliest period of erosion could be accounted for by regional sea-level changes, three events were closely tied to volcanic activity in the form of airfall tephras, and the cause of two others was more likely due to tectonic factors than to human land-use practices.

Turning to evidence from plant microfossils, analyses of phytolith and starch assemblages taken from excavations on Garua Island and the Willaumez isthmus region (Boyd et al. 2005, Lentfer and Torrence 2007) indicate that humans were using fire to create breaks in the forest at least by the early Holocene (and possibly before that). By the middle Holocene this practice prevented natural succession following volcanic eruptions. Based on the presence of phytoliths, a series of economically useful plants was introduced through time beginning in the period after the $\mathrm{W}-\mathrm{K} 1$ eruption. Both the plant microfossils and studies of tool use show that there was little if any changed land use from before to after the $\mathrm{W}$-K2 eruption (i.e., pre- and contemporary with Lapita pottery) (Kononenko 2007, Lentfer and Torrence 2007), contrary to previous predictions for an increase in the intensity of land use through time (Torrence et al. 2000, Torrence 2002a). Overall, there was a very slow increase in the intensification of landscape clearance after earliest settlement, but humans did not make a major impact on natural vegetation until after the last major volcanic eruption $(\mathrm{Dk} / \mathrm{W}-\mathrm{K} 4)$ roughly $1,310-1,170$ years ago, when there was a quantum leap in the degree of human interference in the successional sequence (Boyd et al. 2005, Lentfer and Torrence 2007). Population levels, as monitored by the rate of deposition of obsidian artifacts, also follow the same pattern of very slow increase until after the major Witori and Dakatau eruptions had ceased (Torrence and Doelman 2007: 56).

Pulling all the threads together (erosion, plant macrofossils, nature and intensity of tool use, and population levels), it is clear that the high frequency of severe volcanic disasters restricted the influence of human impacts on the historical ecology of the Willaumez Peninsula in comparison with other more stable environments described, for example, in Kirch and Hunt (1997). The volcanic disasters intervened relatively frequently to grossly remodel the landscape and reset the ecosystem back to an early stage of succession, so perhaps there was less possibility for severe disruption of the ecosystem by human land practices, because the ecosystems had already been disturbed by volcanic activity. On the other hand, the volcanic eruptions may also have opened up new opportunities for populations. If human groups returned to the region during the early stages of succession, they would not have been forced to clear primary rain forest to establish gardens. Following proposals by Denevan $(2001,2004)$ for the history of agriculture in Amazonia, it might have made sense for the first colonizers to develop techniques to maintain the soil fertility of their plots and/or to restrict regrowth in a swidden system of cultivation to secondary forest rather than adopt a wide-scale system of shifting cultivation that required clearance of primary forest.

\section{MEMORY}

Many human societies retain the memories of previous volcanic disasters through oral traditions, myths, and religious practices. These may have played a beneficial role by providing the impetus to avoid dangerous areas, by alerting people about the onset of volcanic hazards, and by encouraging evacuation before the explosive phase of the eruption began, as has been observed with recent volcanic events elsewhere in the South Pacific region (e.g., Lentfer and Boyd 2001, Cronin and Cashman 2007, Gaillard et al. 2007; cf. Chester and Duncan 2007).

Based on case studies in other areas of the world, we would also predict that volcanic disasters might be creatively incorporated into social practice and memory, especially within ritual and ideology (Grattan and Torrence 2007:10-11) (e.g., examples in Blong 1982, Plunket and Uruñuela 1998, Elson et al. 2002, Chester and Duncan 2007, Dillian 2007, Holmberg 2007). To date there is very little evidence about how people in the Willaumez Peninsula conceived of volcanic activity and if they incorporated these concepts 
into their daily lives. A broken Lapita pot recovered from a modern spring in a location near geothermic activity (Specht and Torrence 2007a:90) may suggest ritual activity. Obsidian artifacts commonly found near hot springs and geysers in this region may also indicate that these areas held special significance. Finally, it is worth noting that because the important Kutau/Bao obsidian source was formed by an eruption that occurred after the region was first colonized, populations may have associated the obsidian with a powerful and frightening event. The ascription of special meaning to this stone may therefore help explain why material from this source and not others derived from the Willaumez Peninsula was most highly favored throughout prehistory and was the only obsidian widely dispersed outside the immediate region (Torrence et al. 2004a,b, Summerhayes 2007; cf. Dillian 2007).

On the contrary, it could be argued that catastrophic environments provide little opportunity for memory because of high mortalities, long periods of abandonment, the remodeling of the landscape, and the removal of potential landmarks (Torrence and Doelman 2007:53-55). It is possible that some memories were retained among societies in the Willaumez Peninsula despite catastrophic environmental changes. For instance, the recolonization of inland regions was very rapid in some areas, suggesting that people had deliberately returned to familiar places. One example is Lapita-style pottery, found on the hills that had once surrounded the Kulu Bay, although this tidal embayment, heavily favored by populations in earlier periods, had been radically altered and was now an inland swamp. Although these hills might simply be convenient spots for placing dwellings, the deposition of small quantities of pottery away from the coastal settings more typical of that time period might also signify the special significance of these places (Specht and Torrence 2007a:89-90).

\section{HISTORICAL ECOLOGY OF CATASTROPHIC VOLCANIC ENVIRONMENTS}

In a review of human responses to volcanic activity in Central America, Sheets (2007:85; cf. 1999) concluded that "egalitarian societies with low levels of built environments, minimal reliance on intensive agriculture and domesticated staples, and low population densities exhibited the greatest resilience to sudden massive volcanic stresses." Based on our study of a single region, we propose that Sheets' argument is the wrong way around, probably because of his focus on single eruptions rather than exploring the long-term interactions between catastrophic environments and cultural groups. In other words, the small, mobile populations with flexible subsistence and social strategies and long-distance social ties that Sheets described are actually the outcome of evolution within the highly unstable volcanic environments both in New Britain and in Central America. The relative frequency of disasters has acted to keep populations low because these regions are periodically abandoned, but people have also found creative ways to maintain themselves within the region after a volcanic event (e.g., through using social links to provide refuges). In addition, they have adopted subsistence and settlement patterns that enable them to return quickly, for example through targeting areas least affected by tephra falls.

Although, when considered on the time scale of thousands of years, human societies have found ways to persist in volcanic environments, it is questionable to what extent and in what ways they can make a substantial and long-lasting impact on landscapes that are so radically altered periodically. It is in the realm of anthropogenic factors that the historical ecology of volcanic environments, and particularly those with frequent largescale eruptions, may differ from other types of settings. There is much more potential for human activity to disrupt mature ecosystems than those characterized by early stages of succession, because the latter are primarily made up of colonizing species that regenerate quickly. In fact, it is quite difficult to extract the signal of human modifications from those of an ecosystem in the process of recovering from a volcanic eruption (Lentfer and Torrence 2007). It would be very interesting in future research to compare and contrast the long-term history of vegetation changes due to human agency in active volcanic environ- 
ments versus those in more stable island environments in the South Pacific.

The Willaumez Peninsula case study raises further issues that would benefit from comparative studies both within the Pacific region and further afield (cf. Torrence and Grattan 2002:11-15). First, a broader range of studies about how humans have coped with, adapted to, and taken advantage of the products of volcanic activity is required to see if there are common strategies that have been developed across volcanic environments. To begin with, comparative studies of cultural disasters should examine variation in the strength and frequency of the environmental forcing agencies and identify the factors that have had the most impact. Second, better information is required concerning strategies that enable groups to survive disasters and, in particular, how they find refuge for long periods of time outside the afflicted region. We need to know how far afield people successfully find refuge and what social strategies are used to broker access to resources. Are victims limited to areas where they had already established social links, perhaps through exchange? From a methodological point of view, we need to know how to identify the arrival and subsequent impacts of an influx of refugees (e.g., Lilley 2004a,b).

Another important issue demanding research is (re)colonization. It would be interesting to know if there are similarities in the way people have (re)colonized (1) landscapes after volcanic activity versus (2) islands never previously inhabited. Ideally, we would like to understand the relationships among population size (both of the source population and the founding population), subsistence strategies, the length of time a region is abandoned, and the speed with which (re)colonization takes place.

It seems possible that over a long period, populations resident in regions with active volcanism may have devised particular strategies that cope well with frequent cycles of abandonment and recolonization. These might include many of those noted for the Willaumez Peninsula (e.g., high mobility, flexible social forms and subsistence systems, the maintenance of long-distance social ties, the rapid adoption of new technologies, and other forms of cultural behavior). If so, then these groups might be preadapted for colonizing places that have never been settled before. In this light, the presence of obsidian from the Willaumez Peninsula in most of the earliest Lapita sites in Remote Oceania (Summerhayes 2007) may be more informative than just signaling the source of the populations.

\section{CONCLUSIONS}

Returning to our criticism of Spriggs' (1997) summary of the major factors that have shaped the historical ecology in the South Pacific region, it should now be clear that natural disasters, and especially volcanic hazards, demand more serious study than in past studies. Since the influential review of historical ecology edited by Kirch and Hunt (1997), modern disasters, such as the eruption of $\mathrm{Pi}$ natubo and the Aceh tsunami, have no doubt raised the profile of these powerful forces and probably influenced recent archaeological scholarship (e.g., summary in Grattan and Torrence [2007]), although hints about the importance of volcanism in the South Pacific had been in the literature for some time (e.g., Garanger 1972).

In this paper we have used case studies from interdisciplinary research in the Willaumez Peninsula to illustrate the wide range of processes that impact on human groups living within active volcanic environments. We have tried to show that whereas these dynamic settings frequently produce cultural disasters, human groups have also responded creatively to these challenges. No environment is completely stable. All South Pacific islands are affected to some extent by climatic change, and many experience rapid-onset natural disasters, such as cyclones. We have argued that the factors that set active volcanic environments apart from other settings are the frequency of the hazards and the very large scale of their impacts. The next logical step would be to generalize our work even further by assessing the role of different kinds and degrees of (in)stability in the historical ecology of the South Pacific region. 


\section{ACKNOWLEDGMENTS}

We thank the following institutions in Papua New Guinea and their staff for long-term support of our research: National Museum and Art Gallery, National Research Institute, University of Papua New Guinea, West New Britain Provincial Cultural Center, Kimbe Bay Shipping Agencies, New Britain Palm Oil, Ltd., Walindi Plantation and Resort, Mahonia Na Dari Research Station. Numerous colleagues have provided comments, ideas, and various forms of assistance over the years. We especially thank Stephen Athens, Hugh Davies, Trudy Doelman, Richard Fullagar, Matthew Irwin, Peter Jackson, Carol Lentfer, Hiroshi Machida, Chris McKee, Ken Mulvaney, John Namuno, Tanya O'Neill, Jeff Parr, Christina Pavlides, Ed Rhodes, Glenn Summerhayes, Michael Therin, John Webb, and, above all, Jim Specht and Peter White. Finally, we acknowledge the invaluable support and friendship of the local communities where we have worked and the sterling efforts of our Papua New Guinean and international volunteers.

\section{Literature Cited}

Allison, P. 2002. Recurring tremors: The continuing impact of the AD 79 eruption of Mt Vesuvius. Pages 107-125 in R. Torrence and J. Grattan, eds. Natural disasters and cultural change. Routledge, London.

Anderson, A. 1989. Prodigious birds: Moas and moa-hunting in prehistoric New Zealand. Cambridge University Press, Cambridge.

Anson, D., R. Walter, and R. C. Green. 2005. A revised and redated event phase sequence for the Reber-Rakival Lapita site, Watom Island, East New Britain Province, Papua New Guinea. Univ. Otago Stud. Prehist. Anthropol. 20.

Araho, N., R. Torrence, and J. P. White. 2002. Valuable and useful: Mid-Holocene stemmed obsidian artefacts from West New Britain, Papua New Guinea. Proc. Prehist. Soc. 68:61-81.

Bedford, S., M. Spriggs, and R. Regenvanu. 2006. The Teouma Lapita site and the early settlement of the Pacific. Antiquity 80:812-828.

Begét, J., C. Gardner, and K. Davis. 2008. Volcanic tsunamis and prehistoric cultural transitions in Cook Inlet, Alaska. J. Volcanol. Geotherm. Res. 176:377-386.

Bird, P. 2003. An updated digital model of plate tectonics. Geochem. Geophys. Geosys. 4:1027, doi:10.1029/2001GC000252.

Blong, R. 1982. The time of darkness: Local legends and volcanic reality in Papua New Guinea. University of Washington Press, Seattle.

1984. Volcanic hazards: A sourcebook on the effects of eruptions. Academic Press, Sydney.

Boyd, W., C. Lentfer, and G. Luker. 1999. Environmental impacts of major catastrophic Holocene volcanic eruptions in New Britain, PNG: A preliminary model for palaeoenvironmental change. Pages 361-372 in J. Kesby, J. Stanley, F. McLean, and L. Olive, eds. Geodiversity: Readings in Australian geography at the close of the 20th century. Australian Defence Force Academy, Canberra.

Boyd, W., C. Lentfer, and J. Parr. 2005. Interactions between human activity, volcanic eruptions and vegetation during the Holocene at Garua and Numundo, West New Britain, PNG. Quat. Res. 64:384398.

Boyd, W., and R. Torrence. 1996. Periodic erosion and human land use on Garua Island, PNG: A progress report. Pages 265-274 in S. Ulm, I. Lilley, and A. Ross, eds. Australian Archaeology '95: Proceedings of the 1995 Australian Archaeological Association Annual Conference, Tempus 6. University of Queensland, St. Lucia.

Cashman, K. V., and G. Giordano, eds. 2008. Volcanos and human history. J. Volcanol. Geotherm. Res. 176:325-438.

Chester, D., and A. Duncan. 2007. Geomythology, theodicy, and the continuing relevance of religious worldviews on responses to volcanic eruptions. Pages 203-224 in J. Grattan and R. Torrence, eds. Under the shadow: The cultural impacts of volcanic eruptions. Left Coast Press, Walnut Creek, California. 
Collerson, K., and M. Weisler. 2007. Stone adze composition and the extent of ancient Polynesian voyaging and trade. Science (Washington, D.C.) 28:1907-1911.

Crittenden, K., and K. Rodolfo. 2002. Bacolor town and Pinatubo Volcano, Philippines: Coping with recurrent lahar disaster. Pages 43-65 in R. Torrence and J. Grattan, eds. Natural disasters and cultural change. Routledge, London.

Cronin, S. 2006. Impacts of gas and ash eruptions on pastoral and subsistence agriculture. Pages 19-20 in Abstracts volume, Fourth Conference, Cities on Volcanoes, International Association for Volcanology and Chemistry of the Earth's Interior, Quito, Ecuador.

Cronin, S., and K. Cashman. 2007. Volcanic oral traditions in hazard assessment and mitigation. Pages 175-202 in J. Grattan and R. Torrence, eds. Under the shadow: The cultural impacts of volcanic eruptions. Left Coast Press, Walnut Creek, California.

Cronin, S., and V. Neall. 2000. Impacts of volcanism on pre-European inhabitants of Taveuni, Fiji. Bull. Volcanol. 62:199-213.

Cronin, S., K. Nemeth, and V. Neall. 2008. Volcanism and archaeology. Pages 21852196 in D. Pearsall, ed. Encyclopedia of archaeology. Vol. 3. Academic Press, New York.

Davies, H. 2002. Tsunamis and the coastal communities of Papua New Guinea. Pages 28-42 in R. Torrence and J. Grattan, eds. Natural disasters and cultural change. Routledge, London.

Denevan, W. M. 2001. Cultivated landscapes of native Amazonia and the Andes. Oxford University Press, Oxford.

. 2004. Semi-intensive pre-European cultivation and the origins of anthropogenic dark earths in Amazonia. Pages 135-143 in B. Glaser and W. I. Woods, eds. Amazonian dark earths: Explorations in space and time. Springer, London.

Dillian, C. 2007. Archaeology of fire and glass: Cultural adoption of Glass Mountain in obsidian. Pages 253-273 in J. Grat$\tan$ and $\mathrm{R}$. Torrence, eds. Under the shadow: The cultural impacts of volcanic eruptions. Left Coast Press, Walnut Creek, California.

Driessen, J. 2002. Towards an archaeology of crisis: Defining the long-term impact of the Bronze Age Santorini eruption. Pages 250-263 in R. Torrence and J. Grattan, eds. Natural disasters and cultural change. Routledge, London.

Elson, M., M. Ort, J. Hesse, and W. Duffield. 2002. Lava, corn, and ritual in the northern Southwest. Am. Antiq. 67:119-135.

Enright, N., and C. Gosden. 1992. Unstable archipelagos: South-west Pacific environment and prehistory since 30,000 B.P. Pages 160-198 in J. Dodson, ed. The naïve lands: Prehistory and environmental change in Australia and the Southwest $\mathrm{Pa}$ cific. Longman, Melbourne.

Firth, R. 1959. Ritual adzes in Tikopia. Pages 149-159 in J. Freeman and W. Geddes, eds. Anthropology in the South Seas. Thomas Avery and Sons, Plymouth.

Fullagar, R., G. Summerhayes, B. Ivuyo, and J. Specht. 1991. Obsidian sources at Mopir, West New Britain Province, Papua New Guinea. Archaeol. Oceania 26:110 114.

Gaillard, J.-C., F. Delfin, E. Dizon, V. Paz, E. Ramos, C. Remotigue, K. Rodlfo, F. Siringan, J. Soria, and J. Umbal. 2007. Planning for the future: A multidisciplinary approach to reconstructing the Buag episode of Mt. Pinatubo, Philippines. Pages 225-252 in J. Grattan and R. Torrence, eds. Under the shadow: The cultural impacts of volcanic eruptions. Left Coast Press, Walnut Creek, California.

Galipaud, J.-C. 2002. Under the volcano: NiVanuatu and their environment. Pages 162-171 in R. Torrence and J. Grattan, eds. Natural disasters and cultural change. Routledge, London.

Garanger, J. 1972. Archéologie des NouvelleHébrides: Contribution à la connaissance des iles du center. ORSTOM, Paris.

Gosden, C., and J. Webb. 1994. The creation of a Papua New Guinean landscape: Archaeological and geomorphological evidence. J. Field Archaeol. 21:29-51.

Grattan, J., M. Brayshay, and R. Schüttenhlm. 2002. "The end is nigh"? Social 
and environmental responses to volcanic gas pollution. Pages 87-106 in R. Torrence and J. Grattan, eds. Natural disasters and cultural change. Routledge, London.

Grattan, J., and D. Gilbertson. 1994. Acidloading from Icelandic tephra falling on acidified ecosystems as the key to settlement abandonment and environmental stress in northern and western Britain. J. Archaeol. Sci. 21:851-859.

Grattan, J., S. Michnowicz, and R. Rabartin. 2007. The long shadow: Understanding the influence of the Laki Fissure eruption on human mortality in Europe. Pages 175-202 in J. Grattan and R. Torrence, eds. Under the shadow: The cultural impacts of volcanic eruptions. Left Coast Press, Walnut Creek, California.

Grattan, J., and R. Torrence. 2007. Beyond gloom and doom: The long-term consequences of volcanic disasters. Pages 1-18 in J. Grattan and R. Torrence, eds. Under the shadow: The cultural impacts of volcanic eruptions. Left Coast Press, Walnut Creek, California.

Heming, R. F., and I. E. Smith. 1969. Notes on the thermal fields of Talasea, Pangalu, and Kasiloi, New Britain, TPNG. Bur. Miner. Resour. Geol. Geophys. Rep. (Canberra) 1969/115.

Hoffmann, A., and P. Parsons. 1997. Extreme environmental change and evolution. Cambridge University Press, Cambridge.

Holmberg, K. 2007. Beyond the catastrophe: The volcanic landscape of Baru, western Panama. Pages 274-298 in J. Grattan and R. Torrence, eds. Under the shadow: The cultural impacts of volcanic eruptions. Left Coast Press, Walnut Creek, California.

Jago, L., and W. Boyd. 2005. How a wet tropical rainforest copes with repeated volcanic destruction. Quat. Res. 63:399-406.

Johnson, L. L. 2002. Natural disasters and cultural change in the Shumagin Islands. Pages 193-203 in R. Torrence and J. Grattan, eds. Natural disasters and cultural change. Routledge, London.

Johnson, R. W. 1976. Late Cainozoic volcanism and plate tectonics at the southern margin of the Bismark Sea, Papua New Guinea. Pages 101-116 in R. W. Johnson, ed. Volcanism in Australia. Elsevier, Amsterdam.

Kirch, P., and T. Hunt. 1997. Historical ecology in the Pacific islands: Prehistoric environmental and landscape change. Yale University Press, New Haven, Connecticut.

Kirch, P., and J. Kahn. 2007. Advances in Polynesian prehistory: A review and assessment of the last decade (1993-2004). J. Archaeol. Res. 15:191-238.

Kononenko, N. 2007. The contribution of use-wear/residue studies of obsidian for understanding changes in settlement and subsistence patterns in West New Britain, Papua New Guinea. Bull. Indo-Pac. Prehist. Assoc. 27:135-143.

Lentfer, C., and W. Boyd. 2001. Maunten paia. Volcanoes, people and environment: The 1994 Rabaul eruption. Southern Cross University Press, Lismore.

Lentfer, C., and R. Torrence. 2007. Holocene volcanic activity, vegetation succession and ancient human land use: Unraveling the interactions on Garua Island, Papua New Guinea, Rev. Palaeobot. Palynol. 143:83-105.

Lilley, I. 2004a. Diaspora and identity in archaeology: Moving beyond the Black Atlantic. Pages 287-312 in L. Meskell and R. Preucel, eds. A companion to social archaeology. Blackwell, Oxford.

- 2004b. Trade and culture history across the Vitiaz Strait, Papua New Guinea. Pages 89-96 in V. Attenbrow and R. Fullagar, eds. A Pacific odyssey: Archaeology and anthropology in the western Pacific. Papers in honour of Jim Specht. Rec. Aust. Mus. Suppl. 29.

Losey, R. J. 2005. Earthquakes and tsunamis as elements of environmental disturbance on the Northwest Coast of North America. J. Anthropol. Archaeol. 24:101-116.

Lowe, D. J., R. M. Newnham, and J. D. McCraw. 2002. Volcanism and early Maori society in New Zealand. Pages 126-161 in R. Torrence and J. Grattan, eds. Natural disasters and cultural change. Routledge, London.

Machida, H., R. Blong, J. Specht, R. Torrence, H. Moriwaki, Y. Hayakawa, B. 
Talai, D. Lolok, and C. Pain. 1996. Holocene explosive eruptions of Witori and Datataua caldera volcanoes in West New Britain, Papua New Guinea. Quat. Int. 34-36:65-78.

Machida, H., and S. Sugiyama. 2002. The impact of the Kikai-Akahoya explosive eruptions on human societies. Pages 313-325 in R. Torrence and J. Grattan, eds. Natural disasters and cultural change. Routledge, London.

Manning, S., and D. Sewell. 2002. Volcanoes and history: A significant relationship? The case of Santorini. Pages 264-291 in R. Torrence and J. Grattan, eds. Natural disasters and cultural change. Routledge, London.

Mastrolorenzo, G., D. Palladino, G. Vecchio, and J. Taddeucci. 2002. The 472 AD Pollena eruption of the Somma-Vesuvius (Italy) and its environmental impact at the end of the Roman Empire. J. Volcanol. Geotherm. Res. 113:19-36.

Mastrolorenzo, G., P. Petrone, L. Pappalardo, and M. Sheridan. 2006. The Avellino 3780-yr-B.P. catastrophe as a worst-case scenario for a future eruption at Vesuvius. Proc. Natl. Acad. Sci. U.S.A. 103:4366-4370.

McKee, C., H. Patia, J. Kuduon, and R. Torrence. 2005. Volcanic hazard assessment of the Krummel-Garbuna-Welcker volcanic complex, southern Willaumez Peninsula, WNB, Papua New Guinea. Geol. Surv. Papua New Guinea Rep. 2005/4.

Neall, V. 1996. Hydrological disasters associated with volcanoes. Pages 395-425 in $\mathrm{V}$. Singh, ed. Hydrology of disasters. Kluwer Academic Publishers, Dordrecht, The Netherlands.

Neall, V., R. Torrence, T. O’Neill, M. Turner, B. Hayward, and W. Boyd. 2007. Reconstructing the impacts of volcanic disasters on Holocene paleoenvironments and human land-use: Willaumez isthmus, New Britain, Papua New Guinea. Quat. Int. 167-168:302-303.

Neall, V., R. Wallace, and R. Torrence. 2008. The volcanic environment for 40,000 years of human occupation on the Willaumez isthmus, West New Britain, Papua New
Guinea. J. Volcanol. Geotherm. Res. 176: 330-343. doi:10.1016/j.jvolgeores.2008.01.037 Newhall, C., and S. Punongbayan, eds. 1996. Fire and mud: Eruptions and lahars of Mount Pinatubo, Philippines. University of Washington Press and Philippine Institute of Volcanology and Seismology, Seattle and Quezon City.

Newhall, C., and S. Self. 1982. The volcanic explosivity index (VEI): An estimate of explosive magnitude for historical volcanism. J. Geophys. Res. 87:1231-1238.

Parr, J., C. Lentfer, and W. Boyd. 2001. Spatial analysis of phytolith assemblages at an archaeological site in West New Britain, Papua New Guinea. Pages 125-134 in G. Clark, A. Anderson, T. Vunidilo, eds. The archaeology of Lapita dispersal in Oceania. Terra Australia 17. Pandanus Books, Canberra.

Pavlides, C. 2006. Life before Lapita: New developments in Melanesia's long-term history. Pages 205-227 in I. Lilley, ed. Archaeology of Oceania: Australia and the Pacific islands. Blackwell, Oxford.

Petrie, C., and R. Torrence. 2008. Assessing the effects of volcanic disasters on human settlement in the Willaumez Peninsula, Papua New Guinea: A Bayesian approach. Holocene 18:729-744.

Plunket, P., and G. Uruñuela. 1998. Preclassic household patterns preserved under volcanic ash at Tetimpa, Puebla, Mexico. Lat. Am. Antiq. 9:287-309.

Pyle, D. 2000. Sizes of volcanic eruptions. Pages 263-269 in H. Sigurdsson, ed. Encyclopedia of volcanoes. Academic Press, San Diego.

Rath, P., and R. Torrence. 2003. Producing value: Stemmed tools from Garua Island, Papua New Guinea. Aust. Archaeol. 57:119-127.

Saltonstall, P., and G. A. Carver. 2002. Earthquakes, subsidence, prehistoric site attrition and the archaeological record: A view from the Settlement Point site, Kodiak Archipelago, Alaska. Pages 172-192 in R. Torrence and J. Grattan, eds. Natural disasters and cultural change. Routledge, London.

Sheets, P. 1992. The Ceren site: A prehistoric 
village buried by volcanic ash in Central America. Harcourt Brace, Fort Worth. 1999. The effects of explosive volcanism on ancient egalitarian, ranked, and stratified societies in Middle America. Pages 36-58 in A. Oliver-Smith and S. Hoffman, eds. The angry earth: Disaster in anthropological perspective. Routledge, New York.

- ed. 2002. Before the volcano erupted: The ancient Ceren village in Central America. University of Texas Press, Austin.

. 2007. People and volcanoes in the Zapotitan Valley, El Salvador. Pages 6789 in J. Grattan and R. Torrence, eds. Under the shadow: The cultural impacts of volcanic eruptions. Left Coast Press, Walnut Creek, California.

Sheets, P., J. Hoopes, W. Melson, B. McKee, T. Sever, M. Mueller, M. Cheanult, and J. Bradley. 1991. Prehistory and volcanism in the Arenal area, Costa Rica. J. Field Archaeol. 18:445-465.

Sheets, P., and B. McKee, eds. 1994. Archaeology, volcanism, and remote sensing in the Arenal region, Costa Rica. University of Texas Press, Austin.

Siebe, C., M. Abrams, J. Macías, and J. Obenholzner. 1996. Repeated volcanic disasters in prehispanic time at Popocatépetl, central Mexico: Past key to the future? Geology 24:399-402.

Sigurdsson, H., S. Carey, W. Cornell, and T. Pescatore. 1985. The eruption of Vesuvius in AD 79. Natl. Geogr. Res. 1:332-387.

Smithsonian Institution. 2005. Garbuna ( $\mathrm{Pa}-$ pua New Guinea): First historically witnessed eruption in October 2005. Bull. Global Volcano Net. 30 (11).

Specht, J. 1981. Obsidian sources at Talasea, West New Britain, Papua New Guinea. J. Polynesian Soc. 90:337-356. 2005. Stone axe blades and valuables in New Britain, Papua New Guinea. Pages 15-22 in C. Gross, H. Lyons, and D. Counts, eds. A polymath anthropologist: Essays in honour of Ann Chowning. Research in Anthropology and Linguistics Monograph 6. Department of Anthropology, University of Auckland, Auckland.
2007. Shaft-hole stone implements of New Britain, Papua New Guinea. Pages 263-275 in A. Anderson, K. Green, and F. Leach, eds. Vastly ingenious: The archaeology of Pacific material culture. Otago University Press, Dunedin.

Specht, J., R. Fullagar, and R. Torrence. 1991. What was the significance of Lapita pottery at Talasea? Bull. Indo-Pac. Prehist. Assoc. 11:281-294.

Specht, J., R. Fullagar, R. Torrence, and N. Baker. 1988. Prehistoric obsidian exchange in Melanesia: A perspective from the Talasea sources. Aust. Archaeol. 27:3-16.

Specht, J., and R. Torrence. 2007a. Lapita all over: Land-use on the Willaumez Peninsula, Papua New Guinea. Pages 71-96 in S. Bedford, C. Sand, and S. Connaughton, eds. Oceanic explorations: Lapita and western Pacific settlement. Terra Australis 26. ANU E-Press, Canberra. http://epress. anu.edu.au/ta26_citation.html.

2007b. Pottery of the Talasea area, West New Britain Province. In J. Specht and V. Attenbrow, eds. Archaeological studies of the middle and late Holocene, Papua New Guinea, Part IV. Tech. Rep. Aust. Mus. 20:131-196. www. australianmuseum.net.au/pdf/publications/ 1476_complete.pdf.

Spriggs, M. 1997. Landscape catastrophe and landscape enhancement: Are either or both true in the Pacific? Pages 80-104 in P. Kirch and T. Hunt, eds. Historical ecology in the Pacific islands: Prehistoric environmental and landscape change. Yale University Press, New Haven, Connecticut.

Steadman, D. 2006. Extinction and biogeography of tropical Pacific birds. University of Chicago Press, Chicago.

Summerhayes, G. 2007. Island Melanesian pasts: A view from archaeology. Pages 1035 in J. Friedlaender, ed. Genes, language and culture history in the Southwest Pacific. Oxford University Press, Oxford.

Summerhayes, G. R., J. R. Bird, R. Fullagar, C. Gosden, J. Specht, and R. Torrence. 1998. Application of PIXE-PIGME to archaeological analysis of changing patterns of obsidian use in West New Britain, Papua New Guinea. Pages 129-158 in 
S. Shackley, ed. Archaeological obsidian studies. Plenum, New York.

Thornton, I. 1996. Krakatau: The destruction and reassembly of an island ecosystem. Harvard University Press, Cambridge.

Torrence, R. 2002a. What makes a disaster? A long-term view of volcanic eruptions and human responses in Papua New Guinea. Pages 292-310 in R. Torrence and J. Grattan, eds. Natural disasters and cultural change. Routledge, London.

. 2002b. Cultural landscapes on Garua Island, PNG. Antiquity 76:766-776.

- 2004a. Now you see it, now you don't: Changing obsidian source use in the Willaumez Peninsula, Papua New Guinea. Pages 115-125 in J. Cherry, C. Scarre, and S. Shennan, eds. Explaining social change: Studies in honour of Colin Renfrew. McDonald Institute for Archaeological Research, Cambridge.

. 2004b. Pre-Lapita valuables in Island

Melanesia. Pages 163-172 in V. Attenbrow and R. Fullagar, eds. A Pacific odyssey: Archaeology and anthropology in the western Pacific. Papers in honour of Jim Specht. Rec. Aust. Mus. Suppl. 29.

. 2005. Valued stone: How so? Pages 357-372 in I. Macfarlane, R. Paton, and M. Mountain, eds. Many exchanges: Archaeology, history, community and the work of Isabel McBryde. Aborig. Hist. Mono. 11. Australian National University, Canberra.

2008. Punctuated landscapes: Creating cultural places in volcanically active environments. Pages 333-343 in B. David and J. Thomas, eds. Handbook of landscape archaeology. Left Coast Press, Walnut Creek, California.

Torrence, R., R. Bonetti, A. Guglielmetti, A. Manzoni, and M. Oddone. 2004a. Importance of source availability and accessibility: A case study from Papua New Guinea. Mediterr. Archaeol. Archaeom. 4:53-65.

Torrence, R., and T. Doelman. 2007. Problems of scale: Evaluating the effects of volcanic disasters on cultural change in the Willaumez Peninsula, Papua New Guinea. Pages 42-66 in J. Grattan and R.
Torrence, eds. Under the shadow: The cultural impacts of volcanic eruptions. Left Coast Press, Walnut Creek, California.

Torrence, R., and J. Grattan. 2002. Trends in the archaeology of disasters. Pages 1-18 in R. Torrence and J. Grattan, eds. Natural disasters and cultural change, Routledge, London.

Torrence, R., V. Neall, T. Doelman, E. Rhodes, C. McKee, H. Davies, R. Bonetti, A. Guglielmetti, M. Manzoni, M. Oddone, J. Parr, and C. Wallace. 2004b. Pleistocene colonization of the Bismarck Archipelago: New evidence from West New Britain. Archaeol. Oceania 39:101-130.

Torrence, R., C. Pavlides, P. Jackson, and J. Webb. 2000. Volcanic disasters and cultural discontinuities in the Holocene of West New Britain, Papua New Guinea. Geol. Soc. Lond. Spec. Mem. 171:225244.

Torrence, R., J. Specht, and R. Fullagar. 1990. Pompeiis in the Pacific. Aust. Nat. Hist. 23:457-463.

Torrence, R., J. Specht, R. Fullagar, and J. R. Bird. 1992. From Pleistocene to present: Obsidian sources in West New Britain Province, Papua New Guinea. Rec. Aust. Mus. 42:83-98.

Torrence, R., J. Specht, R. Fullagar, and G. Summerhayes. 1996. Which obsidian is worth it? Pages 211-224 in J. M. Davidson, G. Irwin, B. F. Leach, A. Pawley, and D. Brown, eds. Oceanic culture history: Essays in honour of Roger Green. New Zealand Archaeological Association, Dunedin.

Torrence, R., and P. Swadling. 2008. Social networks and the spread of Lapita? Antiquity 82:600-616.

Torrence, R., P. Swadling, W. Ambrose, N. Kononenko, P. Rath, and M. Glascock. 2009. Obsidian stemmed tools and MidHolocene interaction. Asian Perspect. 48:118-147.

Torrence, R., and J. Webb. 1992. Report on archaeological research on Garua Island, West New Britain Province, PNG. JulyAugust 1992. Available at National Research Institute, Port Moresby, Papua New Guinea. 
Turner, M., and V. Dale. 1998. Comparing large, infrequent disturbances: What have we learned? Ecosystems 1:493-496.

Vanderhoek, R., and R. Nelson. 2007. Ecological roadblocks on a constrained landscape: The cultural effects of catastrophic Holocene volcanism on the Alaska Peninsula, Southwest Alaska. Pages 153-174 in J. Grattan and R. Torrence, eds. Under the shadow: The cultural impacts of volcanic eruptions. Left Coast Press, Walnut Creek, California.

Wallace, L. M., C. Stevens, E. Silver, R. McCaffrey, W. Loratung, S. Hasiata, R. Stanaway, R. Curley, R. Rosa, and J. Taugaloidi. 2004. GPS and seismological constraints on active tectonics and arccontinent collision in Papua New Guinea: Implications for mechanics of microplate rotations in a plate boundary zone. J. Geophys. Res., Earth Sci. (online: 109, B05404. doi: 10.1029/2003JB002481).

White, J. P. 1996. Rocks in the head: Thinking about the distribution of obsidian in
Near Oceania. Pages 199-209 in J. M. Davidson, G. Irwin, B. F. Leach, A. Pawley, and D. Brown, eds. Oceanic culture history: Essays in honour of Roger Green. New Zealand Archaeological Association, Dunedin.

White, J., C. Coroneos, V. Neall, W. Boyd, and R. Torrence. 2002. FEA site, Boduna Island: Further investigations. Pages 101107 in S. Bedford, D. Burley, and C. Sand, eds. Fifty years in the field. N. Z. Archaeol. Assoc. Mongr. 25, Auckland.

Woodhead, J. D., S. E. Eggins, and R. W. Johnson. 1998. Magma genesis in the New Britain island arc: Further insights into melting and mass transfer processes. J. Petrol. 39:1641-1668.

Zeidler, J., and J. Isaacson. 2003. Settlement process and historical contingency in the western Ecuadorian Formative. Pages 69-123 in J. Raymond and R. Burger, eds. Archaeology of Formative Ecuador. Dumbarton Oaks Research Library and Collection, Washington, D.C. 
